\title{
Modelling methane emissions from natural wetlands by development and application of the TRIPLEX-GHG model
}

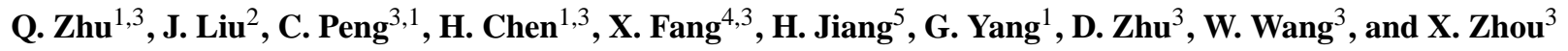 \\ ${ }^{1}$ State Key Laboratory of Soil Erosion and Dryland Farming on the Loess Plateau, Northwest A\&F University, \\ Yangling 712100, China \\ ${ }^{2}$ Contractor, Western Geographic Science Center, U.S. Geological Survey, Menlo Park, CA 94025, USA \\ ${ }^{3}$ Center of CEF/ESCER, Department of Biological Science, University of Quebec at Montreal, Montreal H3C 3P8, Canada \\ ${ }^{4}$ School of Earth Science and Engineering, Hohai University, Nanjing 210098, China \\ ${ }^{5}$ International Institute for Earth System Science, Nanjing University, Hankou Road 22, Nanjing 210093, China \\ Correspondence to: C. Peng (peng.changhui@uqam.ca) and Q. Zhu (qiuan.zhu@gmail.com)
}

Received: 31 August 2013 - Published in Geosci. Model Dev. Discuss.: 4 November 2013

Revised: 27 February 2014 - Accepted: 31 March 2014 - Published: 26 May 2014

\begin{abstract}
A new process-based model TRIPLEX-GHG was developed based on the Integrated Biosphere Simulator (IBIS), coupled with a new methane $\left(\mathrm{CH}_{4}\right)$ biogeochemistry module (incorporating $\mathrm{CH}_{4}$ production, oxidation, and transportation processes) and a water table module to investigate $\mathrm{CH}_{4}$ emission processes and dynamics that occur in natural wetlands. Sensitivity analysis indicates that the most sensitive parameters to evaluate $\mathrm{CH}_{4}$ emission processes from wetlands are $r$ (defined as the $\mathrm{CH}_{4}$ to $\mathrm{CO}_{2}$ release ratio) and $Q_{10}$ in the $\mathrm{CH}_{4}$ production process. These two parameters were subsequently calibrated to data obtained from 19 sites collected from approximately 35 studies across different wetlands globally. Being heterogeneously spatially distributed, $r$ ranged from 0.1 to 0.7 with a mean value of 0.23 , and the $Q_{10}$ for $\mathrm{CH}_{4}$ production ranged from 1.6 to 4.5 with a mean value of 2.48. The model performed well when simulating magnitude and capturing temporal patterns in $\mathrm{CH}_{4}$ emissions from natural wetlands. Results suggest that the model is able to be applied to different wetlands under varying conditions and is also applicable for global-scale simulations.
\end{abstract}

\section{Introduction}

Methane $\left(\mathrm{CH}_{4}\right)$ is an important greenhouse gas, with a 100year global warming potential 28 times stronger than that of carbon dioxide $\left(\mathrm{CO}_{2}\right)$ (Myhre et al., 2013). Atmospheric $\mathrm{CH}_{4}$ concentration in 2011 is $150 \%$ greater than before 1750
(Hartmann et al., 2013). Wetlands, as an important component of the terrestrial ecosystem, play a vital role in the global carbon cycle, which includes a $\mathrm{CH}_{4}$ budget (Zhang et al., 2002; Ciais et al., 2013). $\mathrm{CH}_{4}$ emissions from natural wetlands are the main drivers of the global interannual variability of $\mathrm{CH}_{4}$ emissions with high confidence and contribute largely to interannual variations and anomalies of atmospheric $\mathrm{CH}_{4}$ concentrations (Ciais et al., 2013). Therefore, it is vital to improve existing $\mathrm{CH}_{4}$ emission quantification methods for wetlands to better understand the global $\mathrm{CH}_{4}$ budget (Chen et al., 2013; Kirschke et al., 2013; Nisbet et al., 2014).

Over the last decades, three approaches have generally been used in estimating $\mathrm{CH}_{4}$ emissions from wetlands across different scales: (1) an extrapolation of flux measurements approach, which uses actual $\mathrm{CH}_{4}$ emission measurements to calculate a global estimation, (2) a bottom-up approach, which uses process-based models to calculate $\mathrm{CH}_{4}$ fluxes based on understanding of $\mathrm{CH}_{4}$ emissions and their environmental controls, and (3) a top-down approach, which uses inverse models to estimate the distribution of $\mathrm{CH}_{4}$ sources and sinks by incorporating atmospheric observations (e.g. satellite observations), an atmospheric transport model and prior estimates of source distributions and magnitudes (Arneth et al., 2010; EPA, 2010; Kirschke et al., 2013). The first approach can be unreliable in scaling from point measurements up to regional or global scales due to limitations in spatial and temporal coverage of measurements (Cao et al., 1996). 
The currently used top-down approach - generally believed proficient in covering large regions - may inadvertently include some incomplete observations and error amplifications during inverse modelling processes (Chen and Prinn, 2005; Ciais et al., 2013). Process-based models can be used to improve $\mathrm{CH}_{4}$ emission estimation under different climatic regimes and at the same time cope with the complex interactions that take place between soil, vegetation, and hydrology under $\mathrm{CH}_{4}$ production and consumption processes. The development and application of process-based models could be a practical alternative approach when extrapolating results from site scale to regional or global scale (Cao et al., 1996; Li, 2000; Zhang et al., 2002).

Several process-based models have been developed to estimate global $\mathrm{CH}_{4}$ emissions. Each has its own strategy and features to deal with wetland system complexity and $\mathrm{CH}_{4}$ flux processes (Li, 2000; Walter and Heimann, 2000; Zhuang et al., 2004; Meng et al., 2012). Cao et al. $(1995,1996)$ developed a $\mathrm{CH}_{4}$ emission model for rice paddies based on $\mathrm{C}$ substrate level, soil organic matter (SOM) degradation and environmental control factors and improved it for global natural wetland simulation; but the model has no specific $\mathrm{CH}_{4}$ emission process. Walter and Heimann (2000) and Walter et al. (2001a, b) developed a 1-D process-based climatesensitive model to estimate global long-term $\mathrm{CH}_{4}$ emissions from natural wetlands, forced with net primary production derived by a separate model. Li (2000) developed a denitrification-decomposition model (DNDC) to simulate $\mathrm{CH}_{4}$ emissions but only for rice paddies. Zhang et al. (2002) adopted the DNDC model and some of its key components to simulate wetland ecosystem emissions. Zhuang et al. (2004) have considered the important freeze-thaw processes and integrated methanogenesis modules into the Terrestrial Ecosystem Model (TEM), but only applied it to estimate net $\mathrm{CH}_{4}$ emissions in the high-latitude area of the Northern Hemisphere. A process model (PEATLAND) was developed to simulate $\mathrm{CH}_{4}$ flux from peat soils (van Huissteden et al., 2006) and up-scaled for global boreal and Arctic wetland simulations (Petrescu et al., 2010), although the model did not include explicit soil biogeochemical processes. Wania et al. (2010) integrated a $\mathrm{CH}_{4}$ emission module into the modified dynamic global vegetation model Lund-Potsdam-Jena (LPJ) to simulate $\mathrm{CH}_{4}$ emissions from northern peatlands with consideration of permafrost dynamics, peatland hydrology and peatland vegetation. This model was then modified to simulate global net $\mathrm{CH}_{4}$ emissions for northern peatlands, naturally inundated wetlands and rice agriculture soils (Spahni et al., 2011). To characterize uncertainties and feedbacks between $\mathrm{CH}_{4}$ flux and climate, Riley et al. (2011) developed a $\mathrm{CH}_{4}$ biogeochemistry model (CLM4Me) and integrated it into the land component of the Community Earth System Model (CESM) and further analyses were conducted by Meng et al. (2012), but specific plant functional types have not been considered in wetlands.
The Wetland and Wetland $\mathrm{CH}_{4}$ Inter-comparison of Models Project (WETCHIMP), which simulates and compares large-scale wetland characteristics and corresponding $\mathrm{CH}_{4}$ emissions, reported that large uncertainties indeed still exist when estimating $\mathrm{CH}_{4}$ emissions (Melton et al., 2013; Wania et al., 2013). These uncertainties are generally introduced from large temporal and spatial variations in $\mathrm{CH}_{4}$ flux, with the complex processes that underlie $\mathrm{CH}_{4}$ emissions and also the limited inherent range of field and laboratory measurements (Arneth et al., 2010; Wania et al., 2010; Spahni et al., 2011; Meng et al., 2012). Therefore, further development of process-based $\mathrm{CH}_{4}$ emission models is critical (Walter and Heimann, 2000; Ito and Inatomi, 2012). A dynamic global vegetation model (DGVM) generally combines vegetation dynamics, biogeochemistry, and biogeography processes to predict terrestrial ecosystem response to rapid climate change (Prentice et al., 1989; Cramer et al., 2001). Integrating the $\mathrm{CH}_{4}$ emissions module into a DGVM would be an efficient approach to reflect interactions between hydrology, vegetation, soil and $\mathrm{CH}_{4}$-related processes, and subsequently reducing uncertainties in $\mathrm{CH}_{4}$ emission estimation at different spatial and temporal scales (Arneth et al., 2010; Tian et al., 2010; Wania et al., 2010). It would also be a practical approach to apply when predicting spatial and temporal patterns of $\mathrm{CH}_{4}$ emissions under different future climate change scenarios (Gedney et al., 2004; Shindell et al., 2004; Tian et al., 2010; Stocker et al., 2013). To date, only a few DGVM models have an integrated $\mathrm{CH}_{4}$ emission module (Wania et al., 2010; Spahni et al., 2011).

Therefore, a new model development framework of TRIPLEX-GHG in which a $\mathrm{CH}_{4}$ emission model based on a synthesis of the previous studies discussed was integrated into a DGVM of the Integrated Biosphere Simulator (IBIS). The IBIS is designed to integrate a variety of terrestrial ecosystem functions within a physically consistent modelling framework and represents land surface processes, canopy physiology, vegetation phenology, long-term vegetation dynamics and carbon exchange (Foley et al., 1996; Kucharik et al., 2000). In addition, a water table simulation module based on the approach developed by Granberg et al. (1999) was also integrated into the IBIS and a new plant function type for wetland was added as well. The objectives of the current study are to: (1) integrate biogeochemicalbased methanogenesis processes into a DGVM, which includes explicit description of the processes of $\mathrm{CH}_{4}$ production, oxidation and transportation, for the interactions between hydrology (e.g. water table), vegetation (e.g. specific plant function type in wetlands, primary production) and soil biogeochemistry; (2) make the model applicable throughout global natural wetlands by adjusting a few sensitive parameters. 


\section{Model description and key processes}

The TRIPLEX-GHG model (Peng et al., 2013) is based on the legacy of well-established and published models that include IBIS (Foley et al., 1996), DNDC (Li, 2000), TRIPLEX (Peng et al., 2002) and CASACNP (Wang et al., 2010). However, the scope of this study was only to introduce the development of the new wetland water table and the methanogenesis modules. The basic concept and structure of $\mathrm{CH}_{4}$ emission and water table models and their integration into the IBIS are presented in Fig. 1 and details are described below.

IBIS represents vegetation with plant functional types (PFTs) characterized in terms of biomass and leaf area index (LAI) to simulate changes in vegetation structure on an annual time step through PFT sunlight and water competition (Foley et al., 1996; Kucharik et al., 2000, 2006). For wetland simulations, a new PFT was added in the model. Most of the PFT phenological and physiological parameters were adopted from the $\mathrm{C} 3$ grass PFT in the original IBIS model. The definition of inundation stress effects on gross primary productivity (GPP) of the added PFT in wetlands followed the assumption made by Wania et al. (2009a), that sphagnum and $\mathrm{C} 3$ graminoids photosynthesis will increase or decrease when water table rises or drops.

\subsection{Water table module}

Since the water table is an essential factor in determining anoxic and oxic soil zone extent where $\mathrm{CH}_{4}$ is produced and oxidized, respectively, a water table simulation module was integrated into the IBIS. The module primarily follows the approach developed by Granberg et al. (1999) and the approach has been applied to studies by Zhuang et al. (2004), Weiss et al. (2006) and Wania et al. (2009b). Although applications of the water table simulation approach by Granberg et al. (1999) have been primarily carried out for peatlands or mires, the method was extended for water table simulations of natural wetlands in addition to peatlands for this study. Water balance is the basis of water table simulations. Two zones separated by water table surface were specified for wetlands: the anoxic zone (saturated zone) and the oxic zone (unsaturated zone). Positioning of the water table is subject to soil moisture change, i.e. the input and output volume of water in a specific location. The assumption is that standing water can occur above the land surface and that the drainage process through the bottom of the soil layers can be omitted. When the position of water table is higher than maximum standing water, excess water will be released as runoff. The water budget in the wetland soil profile was derived from the deficit of water input (precipitation) and water output (evapotranspiration and runoff). The water table is estimated by the equation provided below, which was also described in the studies of Granberg et al. (1999) and Wania et al. (2009b):
Water_Table $= \begin{cases}V_{\mathrm{tot}}-Z_{\mathrm{acro}} \phi & \text { if WT }>0 \\ -\sqrt{\frac{3.0 \cdot\left(Z_{\mathrm{acro} o} \phi-V_{\mathrm{tot}}\right)}{2.0 \cdot A_{z}}} & \text { if WT } \leq Z_{\theta_{\mathrm{s}, \min }} \\ -\frac{3.0 \cdot\left(Z_{\mathrm{accro} o} \phi-V_{\mathrm{tot}}\right)}{2 \cdot 0 \cdot\left(\phi-\theta_{\mathrm{s}, \min }\right)} & \text { if } \mathrm{WT}>Z_{\theta_{\mathrm{s}, \min }},\end{cases}$

where $V_{\text {tot }}$ is total water content in the soil profile $(\mathrm{cm})$, $Z_{\text {acro }}$ is the maximum water table depth $(30 \mathrm{~cm}$, Frolking and Crill, 1994; Granberg et al., 1999; Zhuang et al., 2004), $\phi$ is the soil porosity (fraction), $\theta_{\mathrm{s}, \min }$ is the minimum volumetric water content at the soil surface $(0.25$, Granberg et al., 1999), $Z_{\theta_{\mathrm{s}, \min }}$ is the maximum depth where evaporation influences soil moisture $\left(10 \mathrm{~cm}\right.$, Granberg et al., 1999). $A_{z}$ is the gradient in the linearly decreasing interval, calculated as $A_{z}=\left(\phi-\theta_{\mathrm{s}, \min }\right) / Z_{\theta_{\mathrm{s}, \text { min }}}$. A negative/positive value of the water table indicates that the water table is below/above the soil surface, respectively.

\subsection{Methane module}

The $\mathrm{CH}_{4}$ emissions module was adapted and integrated from a number of studies and models (Li, 2000; Walter and Heimann, 2000; Zhang et al., 2002; Wania et al., 2010; Riley et al., 2011; Spahni et al., 2011). Three major processes that include $\mathrm{CH}_{4}$ production, transport (ebullition, diffusion, and plant-mediated transport) and oxidation were coupled with the IBIS. $\mathrm{CH}_{4}$ is produced in each soil layer when soil conditions are favourable. The soil layers is 6 and the soil depth is set to $4 \mathrm{~m}$ as in the original IBIS model. The thermal and water balance processes were inherited from IBIS model. For the wetlands methane module, to simulate the dynamics of the water table, we divided the soil profile into 30 layers $(1 \mathrm{~cm}$ per layer) above the maximum water table depth $(30 \mathrm{~cm})$. Thus 30 layers were used to simulate the water table changes and methane emission process. The soil above maximum water table depth was separated into anoxic and oxic zones, where $\mathrm{CH}_{4}$ is produced and oxidized, respectively. The change in $\mathrm{CH}_{4}$ for each time step in each soil layer is determined by the $\mathrm{CH}_{4}$ production magnitude $\left(\mathrm{Pro}_{\mathrm{CH}_{4}}\right)$, oxidation $\left(\mathrm{Oxi}_{\mathrm{CH}_{4}}\right)$, and three transportation pathways (Ebullition: $\mathrm{Ebu}_{\mathrm{CH}_{4}}$, Diffusion: $\mathrm{Dif}_{\mathrm{CH}_{4}}$, and Plant Mediated Transport: $\mathrm{PMT}_{\mathrm{CH}_{4}}$ ). For each soil layer, $\mathrm{CH}_{4}$ flux is the difference between production $\left(\mathrm{Pro}_{\mathrm{CH}_{4}}\right)$ and consumption/emission $\left(\mathrm{Pro}_{\mathrm{CH}_{4}}-\mathrm{Oxi}_{\mathrm{CH}_{4}}-\mathrm{Ebu}_{\mathrm{CH}_{4}}-\mathrm{Dif}_{\mathrm{CH}_{4}}-\right.$ $\mathrm{PMT}_{\mathrm{CH}_{4}}$ ). Total $\mathrm{CH}_{4}$ released to the atmosphere is the sum of the three-way transportation $\left(\mathrm{Ebu}_{\mathrm{CH}_{4}}+\mathrm{Dif}_{\mathrm{CH}_{4}}+\mathrm{PMT}_{\mathrm{CH}_{4}}\right)$ of the total soil profile.

\subsubsection{Methane production}

$\mathrm{CH}_{4}$ production is considered as the final stage of organic matter mineralization under anaerobic conditions (Cao et al., 1996). It depends not only on carbon substrate supply from plant primary production, but also on soil heterotrophic respiration rates and soil environmental conditions (such as the water table, soil temperature and hydrological regimes which 


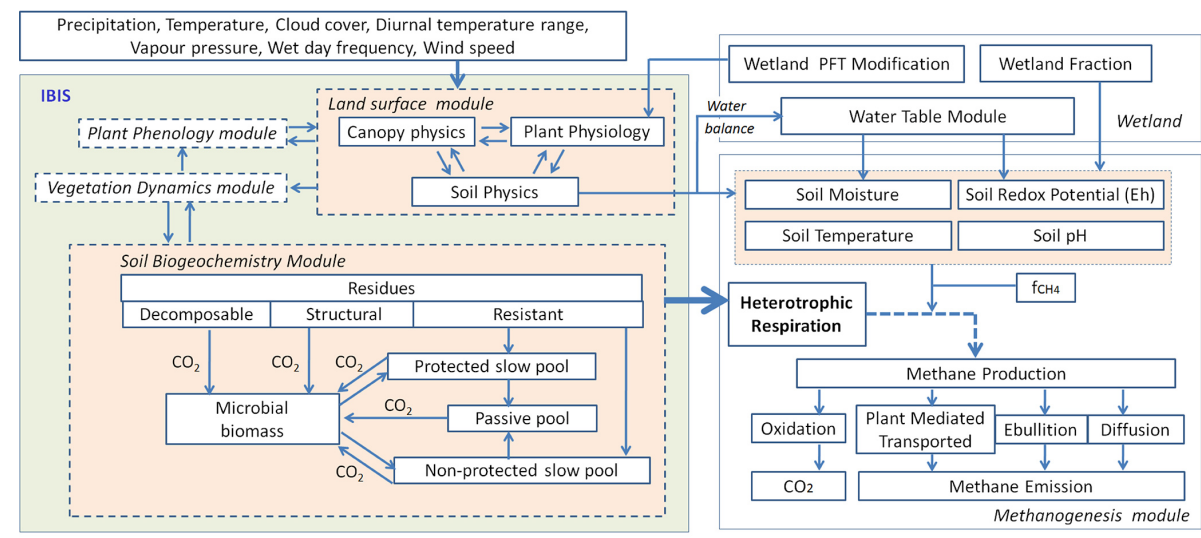

Figure 1. Basic structural concept and integration of $\mathrm{CH}_{4}$ emission and the water table modules into DGVM of IBIS in TRIPLEX-GHG.

define the essential anaerobic conditions for methanogenesis) (Moore and Knowles, 1990; Sass et al., 1990; Whiting and Chanton, 1993; Cao et al., 1996; Walter and Heimann, 2000; Walter et al., 2001b).

$\mathrm{CH}_{4}$ production was calculated as a proportion of heterotrophic respiration $\left(\mathrm{CO}_{2}-\mathrm{C}\right)$ along with soil temperature, $\mathrm{Eh}$ and $\mathrm{pH}$ modification factors as follows:

$\operatorname{Pro}_{\mathrm{CH}_{4}}=R_{\mathrm{H}} \cdot r \cdot f_{\mathrm{STP}} \cdot f_{\mathrm{pH}} \cdot f_{\mathrm{EhP}}$,

where $R_{\mathrm{H}}$ is the soil heterotrophic respiration rate $\left(\mathrm{gC} \mathrm{m}^{-2}\right.$ day $\left.^{-1}\right)$, calculated as the change in soil carbon pool size for each time step by the biogeochemical module in the IBIS. Along with the decomposition processes, carbon flows between different pools including above-ground and below-ground litter pools, a microbial pool, protected and nonprotected pools, and a passive pool. The carbon in litter and soil organic matter is partitioned between microbial biomass and respiration in decomposition processes, with assigned microbial efficiencies for each transformation among pools (Kucharik et al., 2000). A nitrogen feedback is added to control both above-ground carbon assimilation and belowground soil organic carbon decomposition (Liu et al., 2005). $f_{\mathrm{STP}}, f_{\mathrm{pH}}$ and $f_{\mathrm{EhP}}$ represent $\mathrm{CH}_{4}$ production factors of soil temperature, $\mathrm{pH}$ and redox potential, respectively. $r$ is the release ratio of $\mathrm{CH}_{4}$ to $\mathrm{CO}_{2}$.

Many studies have shown that $\mathrm{CH}_{4}$ production is smaller or significantly lower than that found during growing seasons when soil temperature is below $0^{\circ} \mathrm{C}$ (Whalen and Reeburgh, 1992; Shannon and White, 1994). $\mathrm{CH}_{4}$ emissions during winter are suggested to be produced during the previous growing seasons and stored in the soil profile (Dise, 1992; Melloh and Crill, 1996). Therefore, $\mathrm{CH}_{4}$ production was only permitted in the module when soil temperature was above the freezing point $\left(0^{\circ} \mathrm{C}\right)$ and below an extremely high temperature limit $\left(45^{\circ} \mathrm{C}\right.$ in this study). The relationship between soil temperature and $\mathrm{CH}_{4}$ production was adapted from Zhang et al. (2002) as described below:
$f_{\mathrm{STP}}=\left\{\begin{array}{lll}0 & \text { if } & T_{\text {soil }}<0 \\ 0 & \text { if } & T_{\text {soil }}>T_{\max } \\ v t^{x t} \cdot \exp (x t \cdot(1-v t)) \quad \text { if } 0 \leq T_{\text {soil }} \leq T_{\max }\end{array}\right.$

where

$v t=\left(\frac{T_{\max }-T_{\text {soil }}}{T_{\max }-T_{\mathrm{opt}}}\right)$

$x t=\left[\log \left(Q_{10}\right) \cdot\left(T_{\max }-T_{\mathrm{opt}}\right)\right]^{2}$

$\times \frac{\left[1.0+\left(1.0+40.0 /\left[\log \left(Q_{10}\right) \cdot\left(T_{\max }-T_{\text {opt }}\right)\right]\right)^{1 / 2}\right]^{2}}{400}$

and $T_{\max }$ and $T_{\mathrm{opt}}$ are the highest temperature and optimum temperature for $\mathrm{CH}_{4}$ production with values of $45^{\circ} \mathrm{C}$ and $25^{\circ} \mathrm{C}$, respectively. $T_{\text {soil }}$ is soil temperature $\left({ }^{\circ} \mathrm{C}\right)$. For this study, a base $Q_{10}$ value of 3.0 was used (Zhang et al., 2002) for simulations at different calibration sites.

Soil $\mathrm{pH}$ affected methanogenesis with a tolerance range between 5.5 and 9.0 while optimal values ranged between 6.4 and 7.8 with peak values ranging between 6.9 and 7.1 (Wang et al., 1993; Cao et al., 1995). Walter and Heimann (2000) included the effects of $\mathrm{pH}$ on $\mathrm{CH}_{4}$ production in the tuning parameter. The approach by Cao et al. (1995) was adopted here to express the relationship between soil $\mathrm{pH}$ and $\mathrm{CH}_{4}$ production:

$f_{\mathrm{pH}}=\left\{\begin{array}{l}0 \text { if } \mathrm{pH}_{\text {soil }}>\mathrm{pH}_{\text {high }} \text { or } \mathrm{pH}_{\text {soil }}<\mathrm{pH}_{\text {low }} \\ \left(\frac{\mathrm{pH}_{\text {soil }}-\mathrm{pH}_{\text {low }}}{\mathrm{pH} \mathrm{H}_{\text {opt }}-\mathrm{pH}_{\text {low }}}\right) \cdot\left(\frac{\mathrm{pH}_{\text {high }}-\mathrm{pH}_{\text {soil }}}{\mathrm{pH}_{\text {high }}-\mathrm{pH}_{\text {opt }}}\right)^{\frac{\mathrm{pH}_{\text {high }}-\mathrm{HH}_{\text {opt }}}{\mathrm{pH}_{\text {opt }}-\mathrm{pH}_{\text {low }}}}\end{array}\right.$

where $\mathrm{pH}_{\text {low }}$ and $\mathrm{pH}_{\text {high }}$ represent low (4.0) and high (9.0) limitations of $\mathrm{pH}$ effect intervals. The optimal value was set at 7.0. Soil $\mathrm{pH}$ is taken from the soil properties data set. 
Inundation causes low redox potential and promotes an anaerobic soil environment that will stimulate methanogenesis. The soil layer is considered to be inundated below the water table surface and the inundated condition of each soil layer changes with the dynamics of the water table. A linear relationship between soil water table position and $\mathrm{CH}_{4}$ production was previously used to represent the effects of redox potential (Cao et al., 1996). In this study, redox potential changes are determined by water table position, waterfilled pore space (WFPS) fraction, as well as root distribution (Zhang et al., 2002; Zhuang et al., 2004). For the effects of redox potential on methanogenesis, Cao et al. (1995) applied a switch value $(-200 \mathrm{mV})$ for $\mathrm{CH}_{4}$ production processes, while $\mathrm{Li}$ (2000) assumed that $\mathrm{CH}_{4}$ production takes place with a soil Eh level below $-150 \mathrm{mV}$. The relationship between redox potential and $\mathrm{CH}_{4}$ production used in this study was generalized by Zhang et al. (2002), based on the studies by Fiedler and Sommer (2000) and Segers (1998). When redox potential is within a range between $-200 \mathrm{mV}$ and $-100 \mathrm{mV}$, its effect on methanogenesis diminishes linearly from 1.0 to 0.0 . Otherwise, the factor is equal to 1.0 and 0.0 when redox potential is less than $-200 \mathrm{mV}$ and greater than $-100 \mathrm{mV}$, respectively.

The assumption in calculation of the parameter $r$ in the $\mathrm{CH}_{4}$ production adopted here was used in the CLM4Me (Riley et al., 2011; Meng et al., 2012) and LPJ-WHyMe (Wania et al., 2010; Spahni et al., 2011) models, in which $\mathrm{CH}_{4}$ production within the anaerobic portion of the soil column relates to soil heterotrophic respiration, and where the soil carbon for methanogenesis is considered as a fraction of soil heterotrophic respiration.

\subsubsection{Methane oxidation}

$\mathrm{CH}_{4}$ is oxidized by aerobic methanotrophic activities in the soil, taking place in the unsaturated zone above the water table (Cao et al., 1996; Li, 2000; Zhuang et al., 2004). The rate of $\mathrm{CH}_{4}$ oxidation can be calculated based on a linear relationship with GPP (Cao et al., 1996) or as a function of soil $\mathrm{CH}_{4}$ concentration and $\mathrm{Eh}(\mathrm{Li}, 2000)$. Given that $\mathrm{CH}_{4}$ oxidation is primarily controlled by $\mathrm{CH}_{4}$ concentration, redox potential and soil temperature (Segers, 1998), the equation used here is as follows:

$\mathrm{Oxi}_{\mathrm{CH}_{4}}=A_{\mathrm{CH}_{4}} \cdot f_{\mathrm{CH}_{4}} \cdot f_{\mathrm{STO}} \cdot f_{\mathrm{EhO}}$,

$A_{\mathrm{CH}_{4}}$ is the amount of $\mathrm{CH}_{4}$ in each soil layer $\left(\mathrm{gC} \mathrm{m}^{-2}\right.$ layer $\left.{ }^{-1}\right)$. The $\mathrm{CH}_{4}$ concentration factor $\left(f_{\mathrm{CH}_{4}}\right)$ is represented by a Michaelis-Menten kinetic relationship: $C_{\mathrm{CH}_{4}} /\left(K_{\mathrm{CH}_{4}}+C_{\mathrm{CH}_{4}}\right)$, where $C_{\mathrm{CH}_{4}}$ is the $\mathrm{CH}_{4}$ concentration ( $\mu \mathrm{mol} \mathrm{L}{ }^{-1}$ ) and $K_{\mathrm{CH}_{4}}$ is the half-saturation coefficient with respect to $\mathrm{CH}_{4}$ and set to $5 \mu \mathrm{mol} \mathrm{L}{ }^{-1}$ (Walter and Heimann, 2000; Zhang et al., 2002; Riley et al., 2011). A $Q_{10}$ value of 2.0 based on results from previous studies (Segers, 1998; Walter and Heimann, 2000; Zhang et al., 2002) was used to quantify soil temperature effects on $\mathrm{CH}_{4}$ oxidation $\left(f_{\mathrm{STO}}\right)$.
The term for redox potential effects on $\mathrm{CH}_{4}$ oxidation $\left(f_{\text {EhO }}\right)$ was adopted from a general relationship between redox potential and $\mathrm{CH}_{4}$ oxidation reported by Zhang et al. (2002), which was taken from Fiedler and Sommer (2000) and Segers (1998). The redox potential factor was set to zero and 1.0 when Eh was below $-200 \mathrm{mV}$ and above $200 \mathrm{mV}$, respectively. In the remaining range of -200 to $-100 \mathrm{mV}$ and -100 to $200 \mathrm{mV}$, the effective factors of redox potential were represented by two simple linear functions, varying from 0 to 0.75 and from 0.75 to 1 , respectively.

\subsubsection{Methane emission processes}

In early studies, no specific $\mathrm{CH}_{4}$ emission process in $\mathrm{CH}_{4}$ modelling existed (Cao et al., 1995, 1996). Generally, major $\mathrm{CH}_{4}$ emission processes, including diffusion, ebullition and plant-mediated transportation, were formulated by the release of more recent models (Li, 2000; Walter and Heimann, 2000; Wania et al., 2010; Riley et al., 2011), as have been considered in this study.

$\mathrm{CH}_{4}$ diffusion between soil layers was estimated here using Fick's law based on the $\mathrm{CH}_{4}$ concentration gradient in the soil profile (Walter and Heimann, 2000; Zhuang et al., 2004). The diffusion coefficient for each soil layer was modelled as follows:

$$
\begin{aligned}
D_{i} & =D_{\mathrm{a}} \cdot f_{\text {coarse }} \cdot f_{\text {tort }} \cdot \text { SoilPoro } \cdot\left(1-\mathrm{WFPS}_{i}\right) \\
& +D_{\mathrm{w}} \cdot \mathrm{WFPS}_{i},
\end{aligned}
$$

where $D_{\mathrm{a}}$ and $D_{\mathrm{w}}$ are the $\mathrm{CH}_{4}$ molecular diffusion coefficients in air with a value of $0.2 \mathrm{~cm}^{2} \mathrm{~s}^{-1}$ and in water with a value of $0.00002 \mathrm{~cm}^{2} \mathrm{~s}^{-1}$, respectively (Walter and Heimann, 2000). $D_{\mathrm{a}}$ and $D_{\mathrm{w}}$ reflect differences in the rate of $\mathrm{CH}_{4}$ molecular diffusion through unsaturated versus saturated soil layers. $f_{\text {coarse }}$ is the relative volume of coarse pores depending on soil texture (fraction) (Zhuang et al., 2004). $f_{\text {tort }}$ is the tortuosity coefficient with a value of 0.66 (Walter and Heimann, 2000). Lastly, SoilPoro is soil porosity and WFPS is the water-filled pore space.

Being a relatively rapid channel for $\mathrm{CH}_{4}$ emissions, bubbles will form as soon as $\mathrm{CH}_{4}$ concentrations in the soil profile exceed a certain threshold (Walter and Heimann, 2000). For $\mathrm{CH}_{4}$ ebullition emission processes, a constant threshold value of $750 \mu \mathrm{mol} \mathrm{L}^{-1}$ (Walter and Heimann, 2000; Zhang et al., 2002) was used in this study.

Vascular plants provide an effective pathway for $\mathrm{CH}_{4}$ transport to the atmosphere (Shannon et al., 1996; Walter and Heimann, 2000). The plant-mediated flux is proportional to $\mathrm{CH}_{4}$ concentration in the soil and is related to the concentration gradient between the soil and the atmosphere (Walter and Heimann, 2000). A simple equation was used to describe plant-mediated emissions based on the plant aerenchyma factor:

$\mathrm{PMT}_{\mathrm{CH}_{4}}=f_{\text {rhi }} \cdot f_{\text {aer }} \cdot \mathrm{CH}_{4 \text { gra }}$, 
where $f_{\text {rhi }}$ is the rhizospheric oxidation factor, suggesting that a relatively large proportion of $\mathrm{CH}_{4}$ will be oxidized in the highly oxic rhizospheric zone before entering plant tissue (Wania et al., 2010). The factor is dependent on plant type and can range between $20 \%$ and $100 \%$ (Strom et al., 2005; Wania et al., 2010) and a constant value of 0.5 was used here (Zhang et al., 2002). $f_{\text {aer }}$ is the plant aerenchyma factor estimated as a function of root length density (converted from root biomass using a specific root length of $2.1 \mathrm{~cm} \mathrm{mg}^{-1}$ ), the area of the cross section of a typical fine root (assumed as a constant of $0.0013 \mathrm{~cm}^{2}$ ) and the degree of gas diffusion from root to atmosphere (a scalar determined by the aerenchyma condition of plants) (Zhang et al., 2002). A simplified constant of 0.5 was used as the degree of gas diffusion from root to atmosphere in this study, since the value should be 1 for the plants with well-developed aerenchyma (e.g. grasses and sedges) and be 0 for the plants without aerenchyma (e.g. sphagnum and moss). $\mathrm{CH}_{4 \text { gra }}$ is the $\mathrm{CH}_{4}$ deficit between the soil profile and the atmosphere $\left(\mathrm{gC} \mathrm{m}^{-2}\right.$ layer $\left.^{-1}\right)$.

\subsubsection{Major parameters in methane module}

The major parameters for the $\mathrm{CH}_{4}$ module are presented in Table 1. Some of the parameters adopted values that have been fully discussed and supported in previous studies (Cao et al., 1996; Segers, 1998; Walter and Heimann, 2000; Zhang et al., 2002; Zhuang et al., 2004; Wania et al., 2010; Meng et al., 2012).

\section{Data and method}

\subsection{Study sites}

Observed $\mathrm{CH}_{4}$ emissions data of natural wetlands based on previous studies or field work (19 sites worldwide from 35 studies) were collected for model sensitivity analysis, parameter fitting and calibration. Information related to these wetland sites, including location, wetland type, measurement method and references are summarized in Table 2. The selected sites have a wider geographical spread over low- to mid- to high-latitude regions.

Many of the sites listed in Table 2 have been also used in other $\mathrm{CH}_{4}$ emission modelling tests. Since there were no observed detailed individual plot data in the studies carried out in the Amazon Basin (Bartlett et al., 1988, 1990; Devol et al., 1988; Melack et al., 2004) and South Florida (Burke Jr. et al., 1988; Harriss et al., 1988), with only observed emission rate throughout the regions, region-based average emission rates were compared between prediction and estimation. For some sites where different studies were carried out by different groups in the same or different time period (e.g. Sanjiang plain, Stordalen, Minnesota, Table 2), comparisons were made between the same modelling results and those results from different studies. Observation period modelling results were used for parameter fitting and model performance evaluation. Monthly and yearly emission rates were calculated from simulated daily rates when comparing with monthly and yearly observed data.

\subsection{Input data}

For the regional simulations conducted in the Amazon Basin and South Florida, the CRU-TS 3.1 Climate Database (http://badc.nerc.ac.uk/data/cru) was adopted to construct monthly climate input data for the two regions. Selected variables include cloud cover, diurnal temperature range, precipitation, temperature, vapour pressure and wet-day frequency. For the site-based simulations in China, daily climate data were obtained from the Meteorological Bureau of China. For the other sites, since directly measured climate data was unavailable, the daily climate data (mean, max, min temperature, precipitation, mean wind speed, dew point) were downloaded from the nearest stations to the evaluation sites in the global data set of Global Summary of the Day (GSOD) (http://www7.ncdc.noaa.gov/CDO/cdoselect.cmd? datasetabbv $=\mathrm{GSOD} \&$ countryabbv $=\&$ georegionabbv $=$ ) to drive the model. Being unavailable in GSOD, the stationbased cloud cover data are extracted from the CRU-TS data set for each evaluation site. Climate data used for the model spin-up period were mean observed data for site-based simulation or 30-year (1961-1990) means of the CRU data (http://www.ipcc-data.org/obs/get_30yr_means.html) for regional simulation in Florida and the Amazon Basin.

$\mathrm{CO}_{2}$ concentration data for the simulation period were composed of two parts. Observed $\mathrm{CO}_{2}$ concentrations were used for the period covering 1958-2009, derived by Keeling et al. (2005) from in situ air measurements taken at Mauna Loa Observatory, Hawaii. $\mathrm{CO}_{2}$ concentrations before 1958 were adopted from the IS92a global $\mathrm{CO}_{2}$ concentration yearly data set, derived using a spline fit of Mauna Loa and ice core data (Enting et al., 1994).

The soil classification map used was based on the Digital Soil Map of the World (DSMW), generated from the FAO-UNESCO Soil Map of the World (http://www.fao.org/ geonetwork/srv/en/metadata.show?id=14116). DSMW attributes were connected with the soil properties data set contributed by Batjes (2006) that describes characteristics of soil texture (soil clay, sand and silt fraction) and soil $\mathrm{pH}$. A global soil data set (IGBP-DIS, 2000) was adopted to generate soil carbon data for model initialization.

A global digital elevation model (DEM) with an approximate $1 \mathrm{~km}$ spatial resolution (GTOPO30) was used for the topographic input data.

\subsection{Initial sensitivity analysis for parameters fitting}

For the model parameter fitting, initial sensitivity analysis experiments were conducted to obtain the most sensitive parameters in order to simplify the fitting processes. 
Table 1. List of major parameters in $\mathrm{CH}_{4}$ production, oxidation and transportation.

\begin{tabular}{|c|c|c|c|c|c|}
\hline Process & Parameters & Values & Unit & Description & References \\
\hline \multirow[t]{7}{*}{ Methane production } & $T_{\max }$ & 45 & ${ }^{\circ} \mathrm{C}$ & highest temperature for methane production & This study \\
\hline & $T_{\mathrm{opt}}$ & 25 & ${ }^{\circ} \mathrm{C}$ & optimum temperature for methane production & This study \\
\hline & $\mathrm{pH}_{\text {high }}$ & 9 & - & highest $\mathrm{pH}$ for methane production & $\begin{array}{l}\text { Cao et al. (1996), Zhang et al. (2002), } \\
\text { Zhuang et al. (2004) }\end{array}$ \\
\hline & $\mathrm{pH}_{\text {low }}$ & 4 & - & lowest $\mathrm{pH}$ for methane production & $\begin{array}{l}\text { Cao et al. (1996), Zhang et al. (2002), } \\
\text { Zhuang et al. (2004) }\end{array}$ \\
\hline & $\mathrm{pH}_{\text {opt }}$ & 7 & - & optimum $\mathrm{pH}$ for methane production & $\begin{array}{l}\text { Cao et al. (1996), Zhang et al. (2002), } \\
\text { Zhuang et al. (2004) }\end{array}$ \\
\hline & $r$ & $0.1-0.4$ & - & ratio of $\mathrm{CH}_{4}$ and $\mathrm{CO}_{2}$ & Wania et al. (2010), Zhang et al. (2002) \\
\hline & $Q_{10}$ & $1.7-16$ & - & $Q_{10}$ for methane production & $\begin{array}{l}\text { Dunfield et al. (1993), Walter and } \\
\text { Heimann (2000) }\end{array}$ \\
\hline \multirow[t]{2}{*}{ Methane oxidation } & $K_{\mathrm{CH}_{4}}$ & 5 & $\mu \mathrm{mol}$ & Michaelis-Menten coefficients & $\begin{array}{l}\text { Walter and Heimann (2000), Zhang et } \\
\text { al. (2002) }\end{array}$ \\
\hline & $Q_{10}$ & $1.4-2.4$ & - & $Q_{10}$ for methane oxidation & $\begin{array}{l}\text { Meng et al. (2012), Walter and } \\
\text { Heimann (2000), Zhang et al. (2002), } \\
\text { Segers (1998) }\end{array}$ \\
\hline \multirow[t]{4}{*}{ Methane transport } & $f_{\text {tort }}$ & 0.66 & - & tortuosity coefficient & Walter and Heimann (2000) \\
\hline & $D_{\mathrm{a}}$ & 0.2 & $\mathrm{~cm}^{2} \mathrm{~s}^{-1}$ & $\begin{array}{l}\text { molecular diffusion coefficient of methane in } \\
\text { air }\end{array}$ & Walter and Heimann (2000) \\
\hline & $D_{\mathrm{w}}$ & 0.00002 & $\mathrm{~cm}^{2} \mathrm{~s}^{-1}$ & $\begin{array}{l}\text { molecular diffusion coefficient of methane in } \\
\text { water }\end{array}$ & Walter and Heimann (2000) \\
\hline & $f_{\text {rhi }}$ & 0.5 & - & factor of rhizospheric oxidation & Wania et al. (2010), Zhang et al. (2002) \\
\hline
\end{tabular}

Based on analyses carried out in previous studies, the $Q_{10}$ (for processes of $\mathrm{CH}_{4}$ production and oxidation) and the release ratio of $\mathrm{CH}_{4}$ to $\mathrm{CO}_{2}(r)$ were selected for initial sensitivity analysis for parameter fitting. Obtaining an optimal sensitive parameter combination at each individual site was then attempted. Previous studies have shown that $\mathrm{CH}_{4}$ production and oxidation are primarily dependent on temperature, which is controlled by $Q_{10}$ values (Cao et al., 1996; Walter and Heimann, 2000; Walter et al., 2001a; Riley et al., 2011). The $Q_{10}$ values have large uncertainty with broad ranges (Dunfield et al., 1993; Westermann, 1993), which may be caused by substrate availability (Valentine et al., 1994), as well as the influence of temperature on plant growth and organic matter decomposition (Cao et al., 1996). Some studies have shown observed $Q_{10}$ values ranging from 1.7 to 16 (Dunfield et al., 1993; Valentine et al., 1994) or from 1.7 to 4.7 (Valentine et al., 1994). Cao et al. (1996) used a $Q_{10}$ value of 2.0 while Walter and Heimann (2000) and Walter et al. (2001b) used a $Q_{10}$ value of 6.0. Zhuang et al. (2004) used an ecosystem-specific $Q_{10}$ coefficient to evaluate soil temperature effects on $\mathrm{CH}_{4}$ production at northern high latitudes. The parameter $r$ in the $\mathrm{CH}_{4}$ production was considered as the most important and influencing parameter for $\mathrm{CH}_{4}$ emissions (Wania et al., 2010; Spahni et al., 2011). Cao et al. (1995, 1996) used a constant ratio to represent the proportion of decomposed organic carbon that can be converted to $\mathrm{CH}_{4}$. Walter and Heimann (2000) and Walter et al. (2001b) used a tuning parameter calculated using a simple multiple linear regression of soil organic carbon and mean annual temperature to adjust the amplitude of simulated $\mathrm{CH}_{4}$ emissions.
Zhuang et al. (2004) used an ecosystem-specific potential rate for $\mathrm{CH}_{4}$ production.

Sensitivity is generally expressed as the ratio between a relative change of model output and a relative change of a parameter. The sensitivity index described in Lenhart et al. (2002) was used to quantify sensitivity in this study. The sensitivity index $(I)$ is expressed as a finite difference in approximation of a partial derivative, which indicates the dependence of a variable $(y)$ from a parameter $(x)$ :

$I=\frac{\left(y_{2}-y_{1}\right) / y_{0}}{2 \Delta x / x_{0}}$,

where $y_{0}$ is the model output with an initial parameter of $x_{0}$. The initial parameter value varied by $\pm \Delta x\left(x_{1}=x_{0}-\Delta x\right.$ and $\left.x_{2}=x_{0}+\Delta x\right)$ with corresponding values $y_{1}$ and $y_{2}$. The sign of sensitivity index $(I)$ indicates the direction of the model's reaction to parameter change. According to Lenhart et al. (2002), calculated sensitivity indices are ranked into four classes (small to negligible, medium, high, very high). Model sensitivity to a specific parameter is small to negligible when the absolute value of the sensitivity index is less than 0.05 but very high when the absolute value of the sensitivity index is greater than or equal to 1.0 .

\subsection{Methods for parameter fitting evaluation}

After the initial sensitivity analysis, parameter fitting processes for the selected most sensitive parameters was conducted to find the best combination of site-specific parameters. Indices including root mean square error (RMSE), coefficient of determination $\left(R^{2}\right)$ and index of agreement $(D)$ 


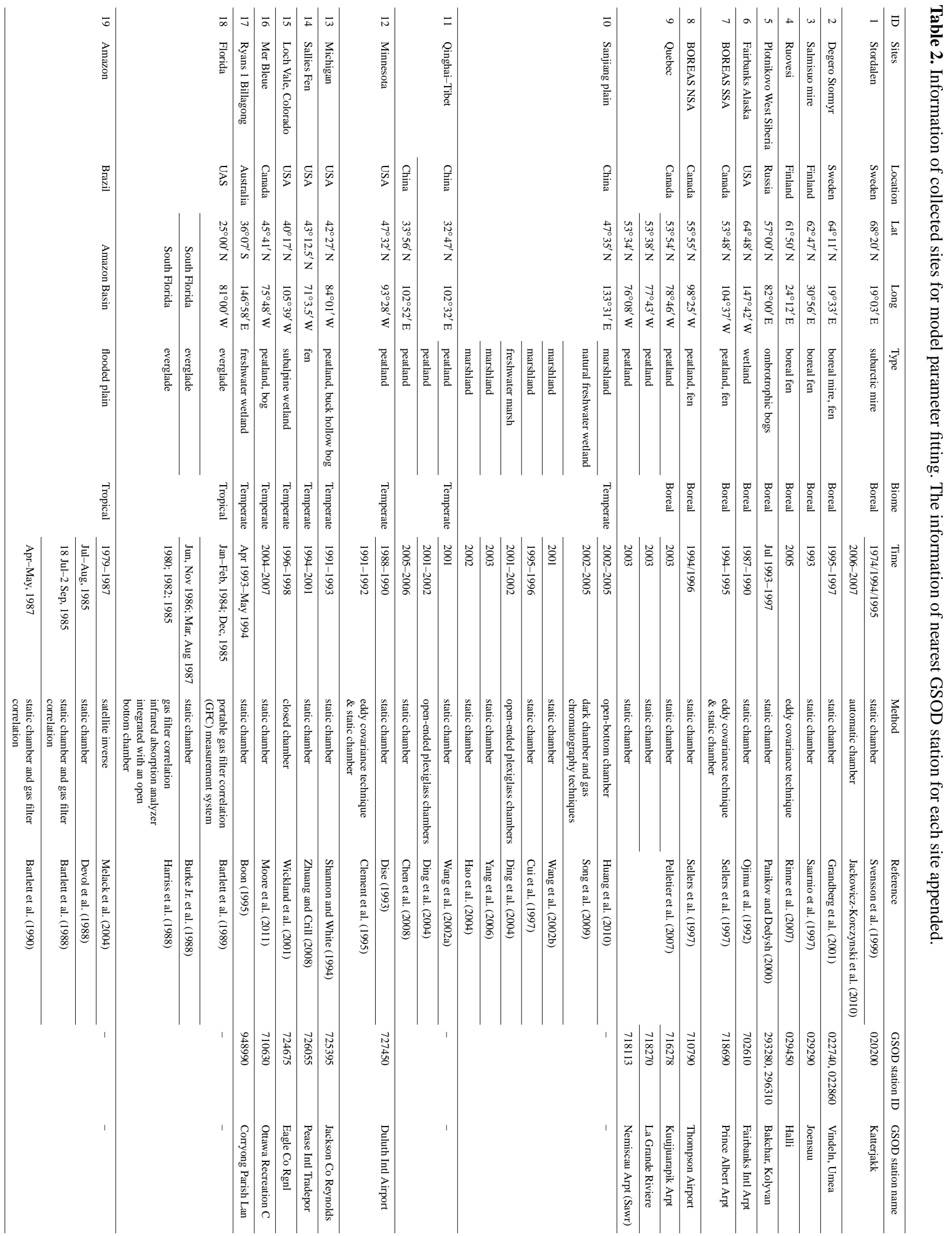




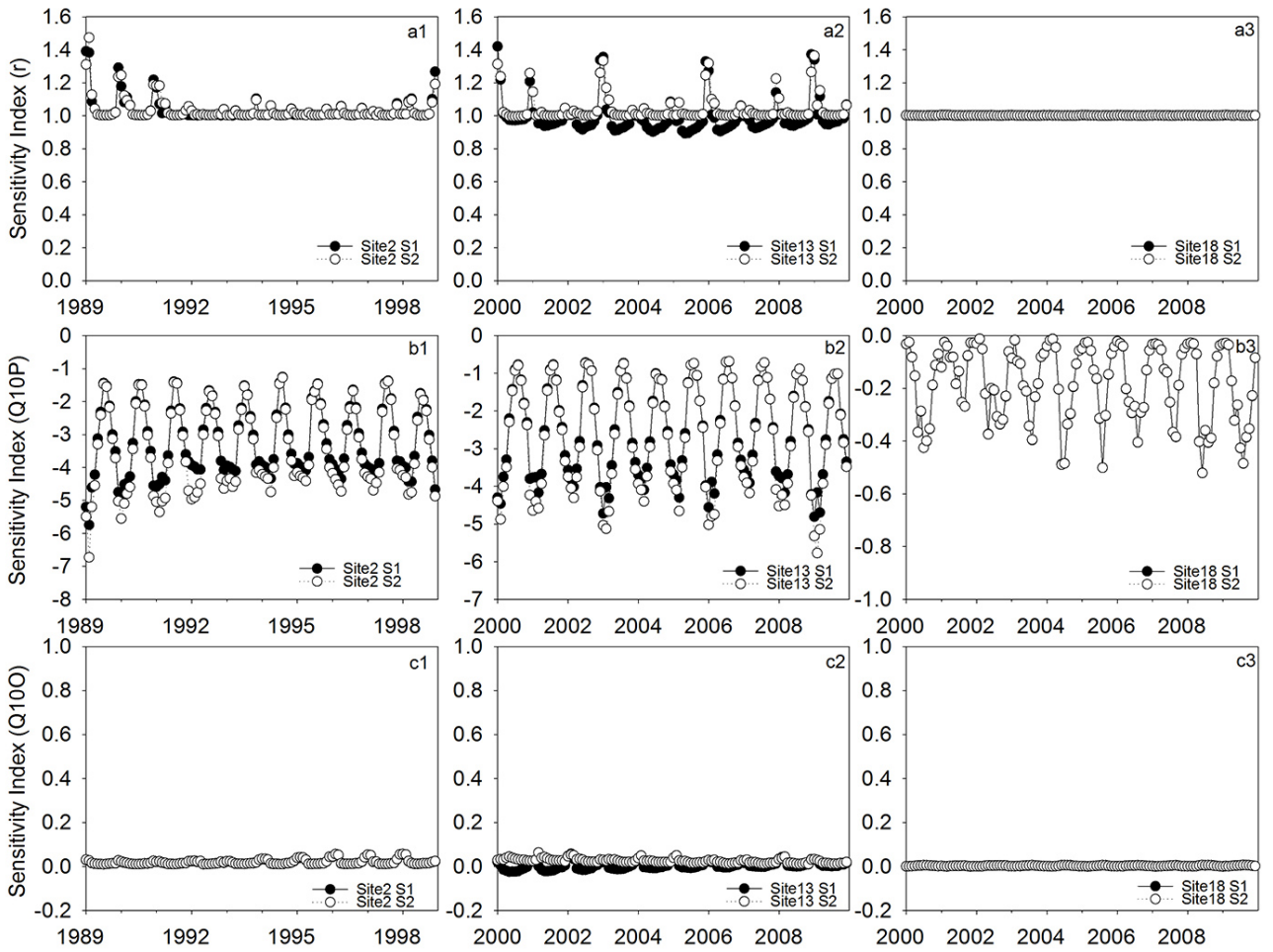

Figure 2. Sensitivity analysis of the three parameters $\left(r, Q_{10} \mathrm{P}, Q_{10} \mathrm{O}\right)$ in the $\mathrm{CH}_{4}$ module at three selected sites for different biome regions: boreal (site 2), temperate (site 12), and tropical (site 18). S1: scenario with single $\Delta x$; S2: scenario with double $\Delta x$.

were used to evaluate the model's performance. The RMSE was calculated as

RMSE $=\sqrt{\frac{\sum_{i=1}^{n}\left(S_{i}-O_{i}\right)^{2}}{n}}$,

where $S$ are the simulated and $O$ the observed values; $n$ is the number of data. The $D$ is calculated as

$D=1-\frac{\sum_{i=1}^{n}\left(S_{i}-O_{i}\right)^{2}}{\sum_{i=1}^{n}\left(\left|S_{i}-\bar{O}\right|+\left|O_{i}-\bar{O}\right|\right)^{2}}$,

where $\bar{O}$ is the average of observed values. $D$ varies between 0 and 1 and it is overly sensitive to extreme values (Willmott, 1981). A $D$ value of 1 indicates a perfect match, and 0 indicates no agreement at all.

\section{Results}

\subsection{Initial sensitivity analysis}

Based on the initial values, $\Delta x$ was set at 0.2 for $Q_{10}$ in $\mathrm{CH}_{4}$ production $\left(Q_{10} \mathrm{P}\right)$ and $\mathrm{CH}_{4}$ oxidation $\left(Q_{10} \mathrm{O}\right)$, and set at 0.05 for the release ratio of $\mathrm{CH}_{4}$ to $\mathrm{CO}_{2}(r)$. Two scenarios were considered, with single $\Delta x(\mathrm{~S} 1)$ and double $\Delta x$ (S2). The initial sensitivity tests were conducted at three sites (site 2 , site 13 and site 18, Table 2) by the biome type (boreal, temperate and tropical regions).

Over different biomes, sensitivity analysis results indicate that $r$ (Fig. 2a1-a3) and $Q_{10} \mathrm{P}$ (Fig. 2b1-b3) were very sensitive, while $Q_{10} \mathrm{O}$ had a very low model sensitivity with a sensitivity index $(I)$ of less than 0.05 (Fig. 2c1-c3). Seasonal patterns of $I$ show that the model was more sensitive to $Q_{10} \mathrm{P}$ during winter than other seasons in boreal (Fig. 2b1) and temperate (Fig. 2b2) regions. In contrast, the model was more sensitive during the summer than other seasons in the tropical region (Fig. 2b3). To simplify parameter fitting and make processes efficient as well as to assess model performance while reducing fluctuating parameters to as few as possible, $Q_{10} \mathrm{O}$ was set as a constant value (2.0) and only two adjustable parameters were chosen $\left(r\right.$ and $\left.Q_{10} \mathrm{P}\right)$ during the parameter fitting discussed below.

\subsection{Model parameterization and calibration}

Calibration sites were categorized into three main biome regions: tropical, temperate and boreal (Table 2). Parameters $r$ and $Q_{10} \mathrm{P}$ were adjusted to yield the best agreement for each site between simulation and observations (Figs. 3-5). The best parameter combination as well as the initial conditions of soil carbon and biomass after spin-up running for 
Table 3. List of calibrated values for the parameters of $r$ and $Q_{10} \mathrm{P}$, the initial soil carbon and biomass conditions, and the model performance criteria indices for each site.

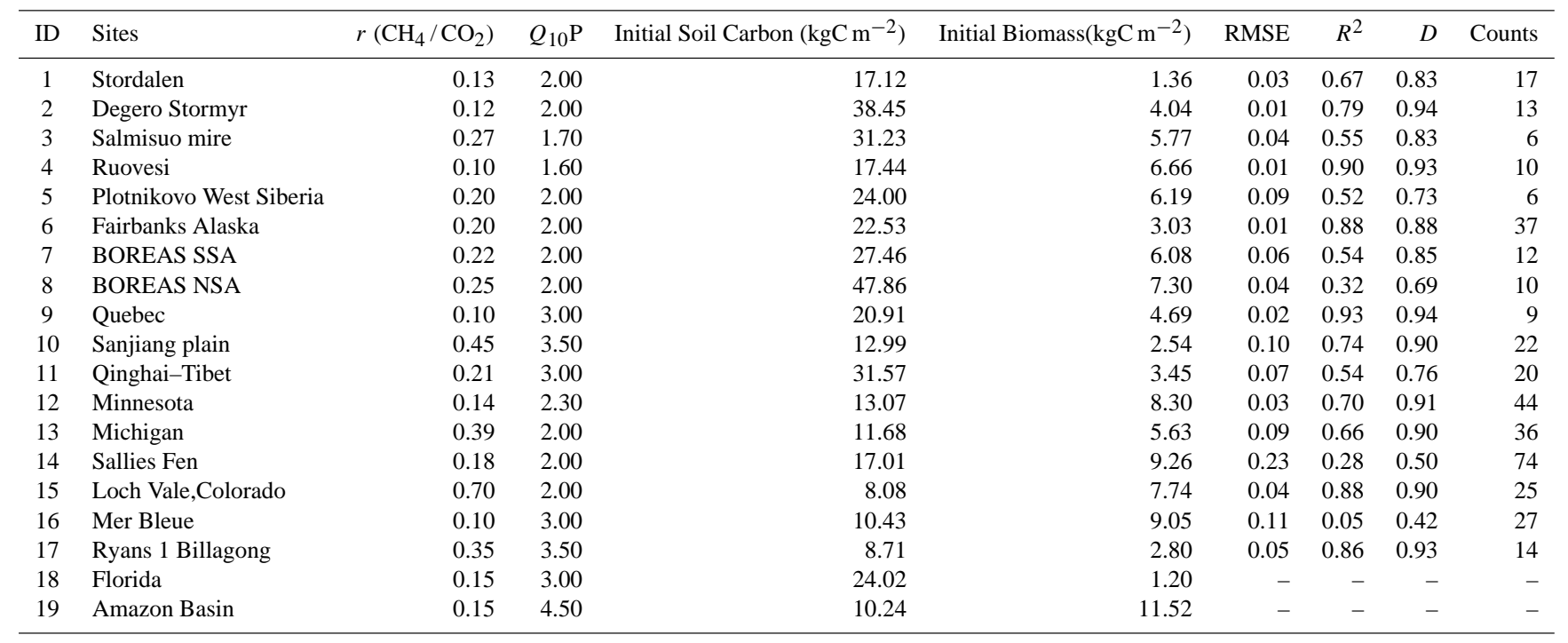

each site are listed in Table 3. The evaluation indices for the model performance were calculated with monthly results as also listed in Table 3. The release ratio of $\mathrm{CH}_{4}$ to $\mathrm{CO}_{2}$ ranged from 0.1 to 0.7 with a mean value of 0.23 , and the $Q_{10}$ value for $\mathrm{CH}_{4}$ production ranged from 1.6 to 4.5 with a mean value of 2.48. Considering the different biome regions of boreal, temperate and tropical, parameter $r$ has mean values of 0.18 , 0.32 , and 0.15 , and parameter $Q_{10} \mathrm{P}$ has mean values of 2.03, 2.66 , and 3.75 , respectively.

\subsubsection{Boreal region}

Data on five natural European wetland sites located in the boreal region were collected, including one subarctic mire site and one boreal mire site in Sweden (Svensson et al., 1999; Granberg et al., 2001; Jackowicz-Korczyński et al., 2010), two boreal fen sites in Finland (Saarnio et al., 1997; Rinne et al., 2007) and one ombrotrophic bog site in Russia (Panikov and Dedysh, 2000).

Svensson et al. (1999) and Jackowicz-Korczyński et al. (2010) took $\mathrm{CH}_{4}$ emission measurements at the same site during different time periods (Fig. 3a, b). The mean emission rate of four wet and semi-dried sites in Svensson et al.'s (1999) study and data observed with the automatic chamber system in Jackowicz-Korczyński et al.'s (2010) study were used for comparison (Fig. 3a, b). $\mathrm{CH}_{4}$ emission rates ranged approximately from 0.02 to $4.9 \mathrm{gC} \mathrm{m}^{-2}$ month $^{-1}$ in the study by Svensson et al. (1999) and approximately from 0.9 to $5.3 \mathrm{gC} \mathrm{m}^{-2}$ month $^{-1}$ in the study by Jackowicz-Korczyński et al. (2010). It was difficult for the model to catch peak values for some years at this location (Fig. 3a, b). For another study (Granberg et al., 2001) carried out in a boreal mire in Sweden, however, the model simulated seasonal $\mathrm{CH}_{4}$ emission variability with reasonable accuracy (RMSE $=0.01, D=0.94$, Fig. 3c).

We have compared modelled results from the current study with mean emission rates of four different vegetation surfaces (hummocks, flarks, Eriophorum lawns and Carex lawns) from a study by Saarnio et al. (1997) (Fig. 3d). Modelled daily $\mathrm{CH}_{4}$ emission rates agreed reasonably with ranges of observed scatter points (RMSE $=0.04, R^{2}=0.55$, $D=0.83$ ) (Fig. 3d), while there was a time lag for the peak simulation.

$\mathrm{A} \mathrm{CH}_{4}$ flux study by Rinne et al. (2007) was measured using the eddy covariance technique. Gap-filling data using linear interpolation in that study was adapted for the modelling test carried out in the current study. Variation in modelled $\mathrm{CH}_{4}$ emissions was consistent with that observed before early July and after mid-September (Fig. 3e). During the period from early July to mid-September, there was a drop in observed emission rates (Fig. 3e). Modelled emission rates showed higher values than observed emission rates during this period (Fig. 3e). Overall, emission rates agreed well between observation and simulation $\left(\mathrm{RMSE}=0.01, R^{2}=0.9\right.$, $D=0.93$ ).

In a study by Panikov and Dedysh (2000), annual variation in $\mathrm{CH}_{4}$ emissions was relatively high, even during the same season. For example, emission rates in July ranged from $3.2 \mathrm{gC} \mathrm{m}^{-2}$ month $^{-1}$ (1997) to $10.8 \mathrm{gC} \mathrm{m}^{-2}$ month $^{-1}$ (1995) (Fig. 3f). The model simulated $\mathrm{CH}_{4}$ emissions at this site reasonably well (RMSE $=0.09, D=0.73$ ) with the exception of those years that exhibited extremely high variation (e.g. 1993 and 1995) (Fig. 3f).

Figure $3 \mathrm{~g}$ and $\mathrm{h}$ show the comparison of $\mathrm{CH}_{4}$ emission rate between model simulations and observations obtained from the Boreal Ecosystem-Atmosphere Study 

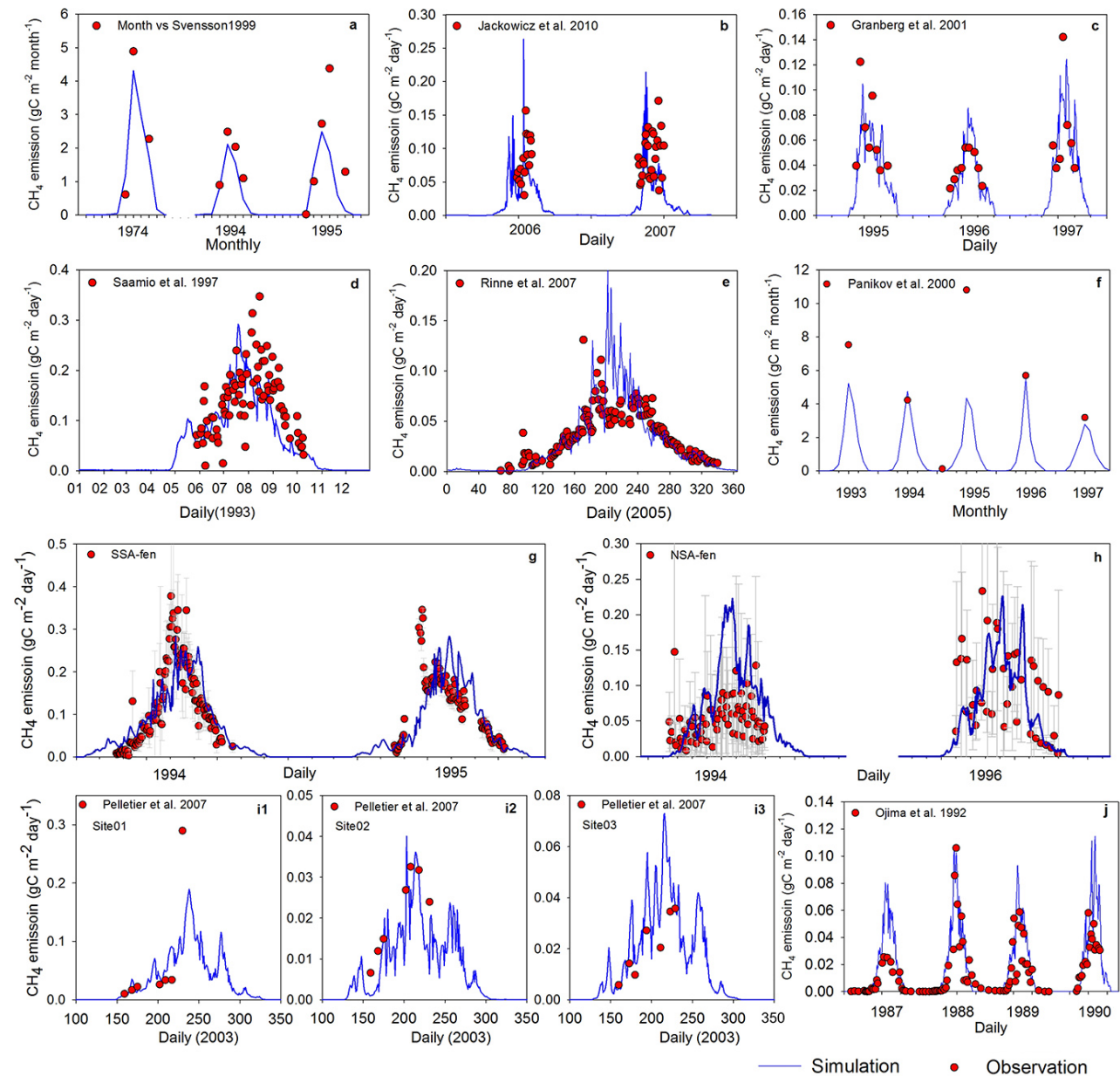

Figure 3. Comparison of modelled and observed $\mathrm{CH}_{4}$ emissions for the sites located in the boreal region.

(BOREAS), a large-scale international interdisciplinary experiment situated in the northern boreal forests of Canada (Sellers et al., 1997). Daily observed $\mathrm{CH}_{4}$ emission rates collected from the Southern Study Area (SSA-fen) and the Northern Study Area (NSA-fen) were used for comparison (http://daac.ornl.gov/BOREAS/bhs/BOREAS_Home.html). The magnitude of observed $\mathrm{CH}_{4}$ emission rates for SSA was approximately twice that for NSA. For NSA, the mean $\mathrm{CH}_{4}$ emission rate for 1996 was nearly twice that of 1994. These patterns indicate high temporal and spatial variation associated with $\mathrm{CH}_{4}$ flux in these areas. The model had better performance in SSA $\left(R^{2}=0.54, D=0.85\right)$ than in NSA $\left(R^{2}=0.32, D=0.69\right)$. For SSA, the model failed to capture the 1994 peak emission. There was an approximate one month delay for the simulated peak emission rate when compared to observed data from 1995. For NSA, the model overestimated the $1994 \mathrm{CH}_{4}$ emissions while 1996 showed relatively better performance.

From a study by Pelletier et al. (2007), observed $\mathrm{CH}_{4}$ emission rates measured on peatland covered by different vegetation types (excluding pools) was averaged for com- parison. Based on the monthly mean emission rates comparison, the simulations agreed well with the observations $\left(\mathrm{RMSE}=0.02, R^{2}=0.93, D=0.94\right)$ (Fig. 3i1-i3).

Observational data of the Fairbanks site (Fig. 3j) was obtained from The United States Trace Gas Network (TRAGNET) online database (http://www.nrel.colostate.edu/projects/tragnet/) described in a workshop reported by Ojima et al. (1992). The model performed well $\left(\mathrm{RMSE}=0.01, R^{2}=0.88, D=0.88\right.$ ) except for some cases of overestimation during growing seasons.

\subsubsection{Temperate region}

Two sites in China were selected to test the model, one in northeast China and one in the Qinghai-Tibet Plateau. Natural wetlands and floodplains in China are primarily located in these two key regions (Ma et al., 2012). Figure 4a and b show comparisons between field measurements and model simulations in the Sanjiang Plain in northeast China. Figure 4a shows mean annual $\mathrm{CH}_{4}$ emissions from wetlands of different plant types in a study by Huang et al. (2010) compared to 
annual $\mathrm{CH}_{4}$ emission rates of inundated marshes in a study by Song et al. (2009). $\mathrm{CH}_{4}$ emission rates reported by Huang et al. (2010) were relatively low. Simulated $\mathrm{CH}_{4}$ emissions for 2002-2003 were much higher than observed. For 20032004, $\mathrm{CH}_{4}$ emission rates were higher for Song et al. (2009) by an approximate magnitude of 2.5 compared to those of Huang et al. (2010). Simulated results were within the range of these two independent studies.

The wetland plant type used in the studies was Carex lasiocarpa (Cui, 1997; Wang et al., 2002b; Ding et al., 2004; Hao et al., 2004; Yang et al., 2006). The peak values (growing season) of observed data in a study by Ding et al. (2004) were slightly higher than modelled results for 2001-2002 while the observed data in a study by Hao et al. (2004) were lower than those reported in a study by Ding et al. (2004) as well as this study's simulation for 2002. The model captured the main variations of observations and agreed well with the mean emission of all observations $\left(R^{2}=0.74, D=0.90\right)$.

For those studies carried out in the Qinghai-Tibet Plateau, modelled peak values were slightly higher than observed data collected from studies with the exception of a 2005 comparison reported in a study by Chen et al. (2008). It was observed that $\mathrm{CH}_{4}$ emission rates reported by Chen et al. (2008) for 2005 were much higher than their reported 2006 emission rates and also higher than emission rates observed by Wang et al. (2002a) and Ding et al. (2004), even though site locations were situated very close to each other (Fig. 4c, d). By comparing all the observations conducted at Qinghai-Tibet Plateau with the model simulations, the model presented relatively low agreement index $(D=0.76)$ due to the mismatch of peak values.

Data on four natural American wetland sites located in the temperate region were collected. Observational data of Sallie's fen was obtained from the National Center for Ecological Analysis and Synthesis (NCEAS) data repository (Zhuang and Crill, 2008). The remaining observed data were obtained from corresponding citations (Fig. 4e-i) (Burke Jr. et al., 1988; Harriss et al., 1988; Bartlett et al., 1989; Dise, 1993; Shannon and White, 1994; Clement et al., 1995; Wickland et al., 2001). Although the model overestimated or underestimated emission rates for some peak values, Fig. $4 \mathrm{e}-\mathrm{i}$ show that general seasonal patterns of $\mathrm{CH}_{4}$ emissions simulated by the model were consistent with observations.

For the site located in north central Minnesota, the mean emission rate was calculated based on observations carried out under different vegetation conditions from a study by Dise (1993). Simulated $\mathrm{CH}_{4}$ emissions were slightly lower than the observed emissions for winter (Fig. 4e) while modelled results agreed better for static chamber measurement than for eddy correlation measurement (Fig. 4f). The model reached an overall agreement index of 0.91 by combining chamber and eddy correlation data.

For the site located in Michigan, observed $\mathrm{CH}_{4}$ emissions collected from three individual flux chambers distributed approximately $10 \mathrm{~m}$ apart in a study by Shannon and
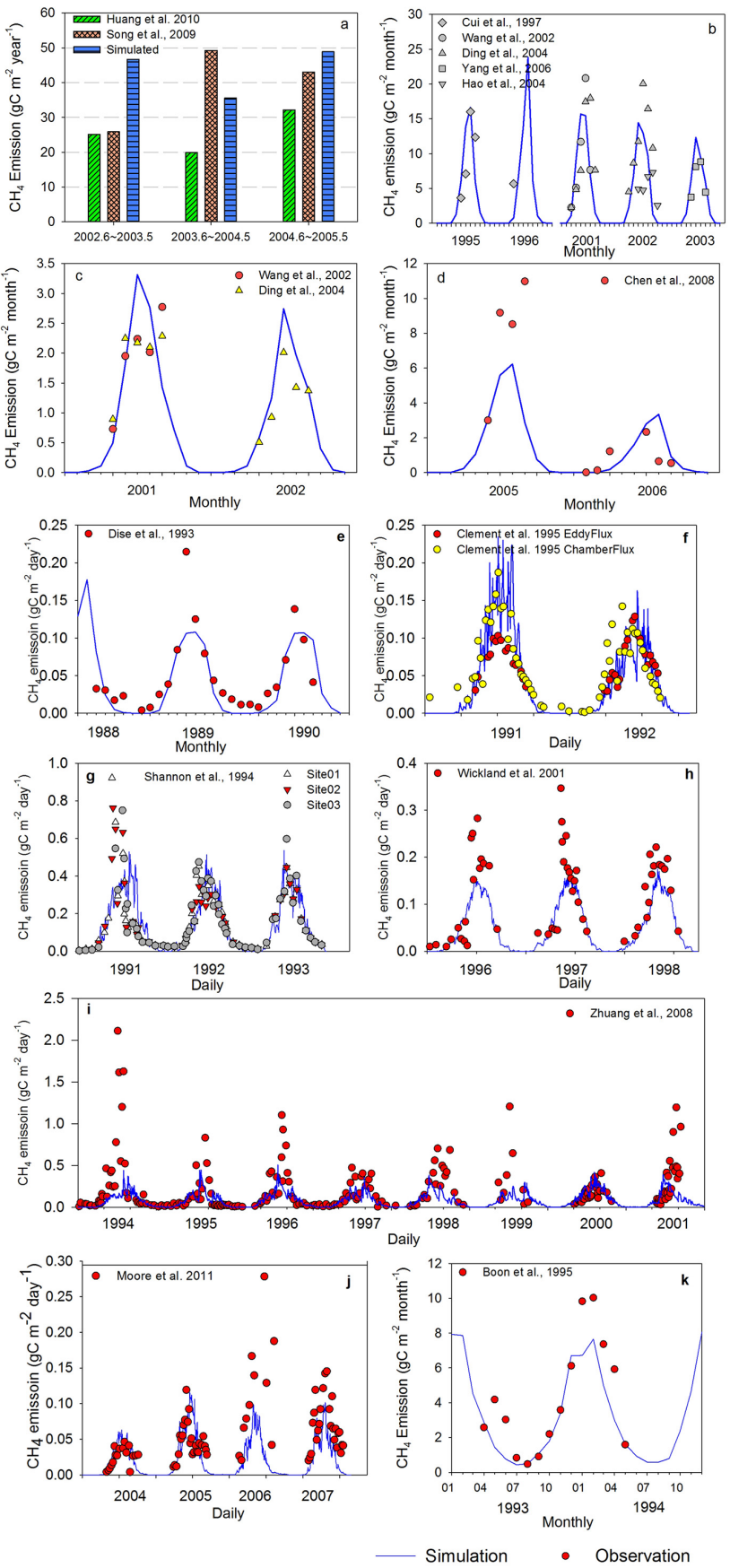

Figure 4. Comparison of modelled and observed $\mathrm{CH}_{4}$ emissions for the sites located in the temperate region.

White (1994) were compared to simulated $\mathrm{CH}_{4}$ emissions on a daily scale for the period 1991-1993 (Fig. 4g). Although the model failed to capture the 1991 summer emission pulse, it performed well for both 1992 and 1993 (Fig. 4g) and showed a good overall agreement index of 0.9 .

For the site in a study reported by Wickland et al. (2001), the model again failed to capture peak emissions during the growing season, but it simulated quite well in the remaining 
seasons (Fig. 4h). Based on the monthly mean emission rates, simulated results agreed well with observations $\left(R^{2}=0.88\right.$, $D=0.90)$.

For the Sallie's fen site (Zhuang and Crill, 2008), simulated seasonal and annual variation agreed well with an 8 -year uninterrupted observation (Fig. 4i). However, it is difficult for the model to capture several peak values during the growing season at this site, especially in 1994 (Fig. 4i), which accounts for the relatively low level of the evaluation index $\left(R^{2}=0.28, D=0.50\right)$.

In comparison with results reported by Moore et al. (2011), the model underestimated $\mathrm{CH}_{4}$ emissions from 2006 to 2007, especially in 2006 (note: three observed value points that were much greater than $0.3 \mathrm{gC} \mathrm{m}^{-2}$ day $^{-1}$ in 2006 are not shown on the graph), but it agreed well with observations from 2004 and 2005 (Fig. 4j). Overall, in the comparison, the index of agreement is low $(D=0.42)$ because the model did not capture the largest and smallest observations.

Additionally, a set of observed $\mathrm{CH}_{4}$ emission data related to freshwater wetlands in southeastern Australia was collected from a study by Boon (1995) where field work was carried out over a 14-month period in 1993 and 1994. Seasonal and annual variation patterns for model simulations and observations stood in good agreement with each other $\left(\mathrm{RMSE}=0.05, R^{2}=0.86, D=0.93\right.$ ) (Fig. $4 \mathrm{k}$ ).

\subsubsection{Tropical region}

Studies carried out in the Florida Everglades have no precise geographical point location; instead, regional averaged modelling results around the Everglades National Park were used for comparison (Fig. 5). Variations in observations ranged from $3.0 \mathrm{mgC} \mathrm{m}^{-2}$ day $^{-1}$ to $481.5 \mathrm{mgC} \mathrm{m}^{-2}$ day $^{-1}$. However, the highest emission rate $\left(481.5 \mathrm{mgC} \mathrm{m}^{-2} \mathrm{day}^{-1}\right)$ was measured in an open-water site while rapid ebullition was observed on all sampling dates (Burke Jr. et al., 1988). This produced extremely high $\mathrm{CH}_{4}$ flux at this particular site. Emissions ranged from $3.0 \mathrm{mgC} \mathrm{m}^{-2}$ day $^{-1}$ to $186.0 \mathrm{mgC} \mathrm{m}^{-2} \mathrm{day}^{-1}$ if excluding the open-water site. Based on grid statistics, the simulated mean $\mathrm{CH}_{4}$ emission for this area was approximately $60.0 \mathrm{mgC} \mathrm{m}^{-2} \mathrm{day}^{-1}$ with a variation of approximately $20.0 \mathrm{mgC} \mathrm{m}^{-2} \mathrm{day}^{-1}$. Modelled emission rate ranges were generally consistent with observed data (Fig. 5a).

Since precise information on field site locations was unavailable for the Amazon Basin, a simple comparison of monthly mean $\mathrm{CH}_{4}$ emissions was made between mean field observations and regional averaged modelled results (Fig. 5b). Modelled monthly $\mathrm{CH}_{4}$ emission rates were close to flooded forest emissions rates reported by Bartlett et al. (1988, 1990). Melack et al. (2004) reported that total annual $\mathrm{CH}_{4}$ emissions from the central Amazon Basin had a mean value of $6.8{\mathrm{TgC} \mathrm{yr}^{-1}}^{-1}$, based on remote sensing estimation. Total emissions for the same area where Melack et al. (2004) carried out their study was evaluated by the current

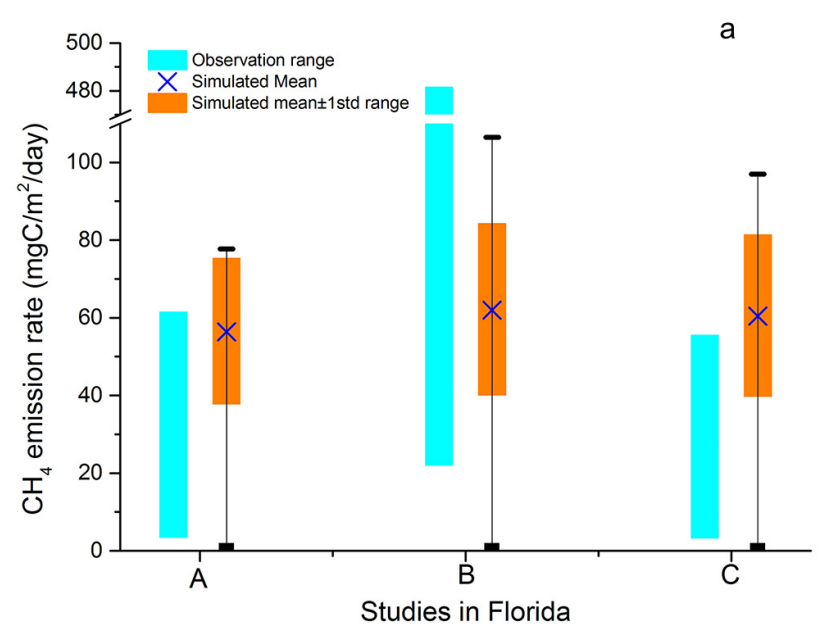

Figure 5a. Comparisons between simulation results of mean (cross symbol) $\pm 1 \mathrm{SD}$ (orange column) and maximum and minimum (short bar) emission rates and observed emissions range (light blue column) of studies A: Bartlett et al. (1989), B: Burke Jr. et al. (1988), C: Harriss et al. (1988) in Florida everglade.

study, based on regional simulations. Modelled annual total emissions were $6.32 \mathrm{TgC} \mathrm{yr}^{-1}$, which was close to the value (6.8) reported by Melack et al. (2004).

\section{Discussion}

Certain assumptions and equations from previous studies and models were adopted by this study in order to construct the $\mathrm{CH}_{4}$ emission model before being integrated into a DGVM (IBIS) model. Parameters relatively high in model sensitivity were determined through initial sensitivity analysis. Wania et al. (2010) tested seven parameters using more than 2000 different parameter combinations; Riley et al. (2011) tested different parameters for $\mathrm{CH}_{4}$ production, consumption and transportation processes; Meng et al. (2012) tested eight parameters for sensitivity within certain possible ranges. For this study, only three parameters were selected $\left(r, Q_{10} \mathrm{P}\right.$, and $\left.Q_{10} \mathrm{O}\right)$ to conduct a series of initial sensitivity analyses. Results show that $Q_{10}$ for $\mathrm{CH}_{4}$ production had a much higher sensitivity level than $Q_{10}$ for $\mathrm{CH}_{4}$ oxidation, and the release ratio of $\mathrm{CH}_{4}$ to $\mathrm{CO}_{2}$ was highly sensitive to $\mathrm{CH}_{4}$ emission processes and had direct impacts on $\mathrm{CH}_{4}$ production. Much stronger temperature dependence during production compared to oxidation was also reported in previous studies (Walter and Heimann, 2000; Walter et al., 2001a; Wania et al., 2010; Riley et al., 2011; Meng et al., 2012), as was the release ratio of $\mathrm{CH}_{4}$ to $\mathrm{CO}_{2}$, being the parameter that most influenced $\mathrm{CH}_{4}$ emissions, with the ratio varying in a large range (Wania et al., 2010; Riley et al., 2011; Spahni et al., 2011; Meng et al., 2012). Therefore, the release ratio of $\mathrm{CH}_{4}$ to $\mathrm{CO}_{2}$ and $Q_{10}$ for $\mathrm{CH}_{4}$ production were selected for 


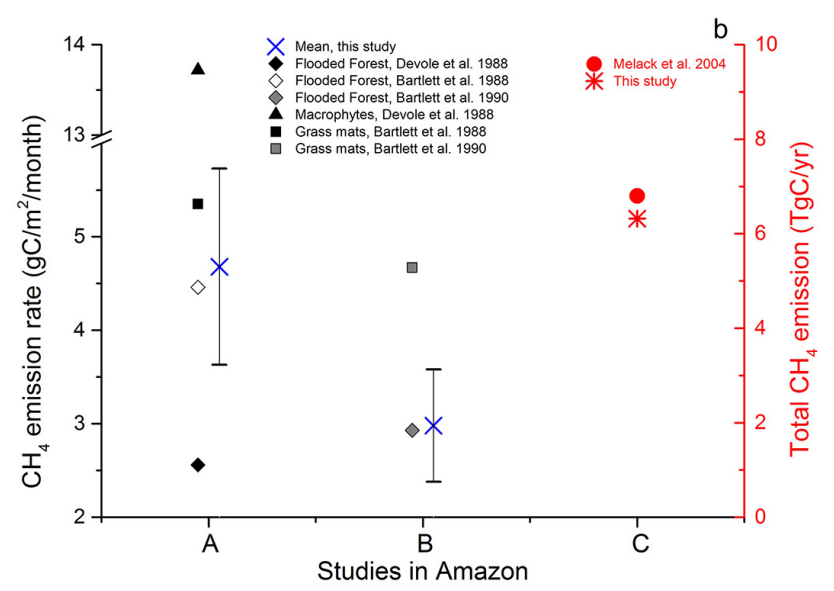

Figure 5b. Comparisons between simulation results of mean (cross symbol) $\pm 1 \mathrm{SD}$ (short bar) and observations from studies of A: Devol et al. (1988) and Bartlett et al. (1988), and B: Bartlett et al. (1990); C: total annual $\mathrm{CH}_{4}$ emission comparison between simulation and the study of Melack et al. (2004) in the Amazon.

parameter fitting in order to ascertain the best combination to test model performance and calibrate for individual sites.

Additionally, sensitivity levels indicate that $Q_{10} \mathrm{P}$ is much more sensitive in winter than summer for northern middleto high-latitude regions, while the reverse pattern is observed in tropical regions. Furthermore, $Q_{10} \mathrm{P}$ has a higher sensitivity level in boreal and temperate regions than in tropical regions. The gradually increasing parameter $Q_{10} \mathrm{P}$ from boreal to temperate to tropical implies that the $\mathrm{CH}_{4}$ emissions from wetlands are more temperature dependent in high-latitude regions than in the tropical region. Parameter $r$ indicates that the release ratio of $\mathrm{CH}_{4}$ to $\mathrm{CO}_{2}$ is higher in the temperate region than the others.

Some simulated results failed to capture peak observed $\mathrm{CH}_{4}$ emission values during the growing season. The underestimation of $\mathrm{CH}_{4}$ emission pulse may be partly due to, on the one hand, external environmental triggers and $\mathrm{CH}_{4}$ contribution from microbial mat systems during summer not being included in the model (Shoemaker and Schrag, 2010; Tian et al., 2010). On the other hand, the ebullition events of short duration, which are often recorded as very high fluxes in the observation, are hard to reproduce (Moore et al., 2011), since some dependent factors (e.g. the density of nucleation site) in $\mathrm{CH}_{4}$ ebullition process are difficult to simulate (Wania et al., 2010). At the same time, some simulated peak emission values were not seen in the observations. One possible explanation could be the low sampling frequency typical of field work. Although some comparisons were carried out between simulations and observations using the high-frequency eddy covariance technique rather than lowfrequency flux chambers, the footprint associated with eddy flux estimation depends on wind properties, boundary layers, surface roughness, etc. (Riley et al., 2011). Nevertheless, the model was able to capture seasonal $\mathrm{CH}_{4}$ emission variation patterns effectively. For example, a drop in observed emission rates was detected in a study by Rinne et al. (2007) during early July to mid-September. It was suggested that the major reason for this emission drop may be due to the fact that the methanogenic microbe population exceeded growth in available substrates (Rinne et al., 2007). At the same time, the green area of the vascular plants reached its maximum (Rinne et al., 2007), which means that more oxygen can be transported to the tips of the roots of the vascular plants. The subsequently high $\mathrm{CH}_{4}$ oxidation rate will also contribute to the emission drop. A drop pattern was also found in our simulation during the same period.

Another reason for the differences between simulation and site observations may be attributed to the uncertainties of driving data. For some sites, climate data were obtained from the nearest meteorological station since climate observations in situ were unavailable. The differences of climate condition between modelling sites and meteorological sites could be large due to the effects of topography and geological location. For the model simulations in the tropical region, a global-scale climate data set was used. The climate data set cannot reflect the details of the daily or seasonal variation in temporal and spatial respects for the given large grid. Local climates may differ significantly from grid climates, especially in regions of high relief (Wania et al., 2010). Biases may be subsequently added to simulations of net primary productivity (NPP), heterotrophic respiration, soil water and thermal processes, which are important parameters for $\mathrm{CH}_{4}$ production. Therefore, it is difficult for the model to capture full emission patterns. The soil property is also difficult to be replicated accurately at site level using a global soil data set, which is also a possible cause for the disagreement between model simulation and observation.

Uncertainties from field observations should also be taken into account in such comparisons. In many studies, for example, observations taken in the first year typically differ from subsequent years. This may be due to the fact that conditions of observational systems are unstable during initial setup. Larger differences are exhibited in the first year between simulations and observations.

It is important to note that two parameter values analysed in this study ( $r$ and $Q_{10} \mathrm{P}$ ) are spatially heterogeneous. For the parameter fitting process, we tried to find the best sitespecific parameter combination and to show how well the model can perform at the local site condition. This will continue to be an important issue for model simulation and development at both regional and global scales. Using different parameter sets or an overall uniform parameter set (e.g. average values for all sites) for site-, region- or global-scale simulations should be considered. Collecting more observed $\mathrm{CH}_{4}$ emissions data sets from different geographic locations and wetland types could produce more reliable parameter sets under different conditions and locations, after which spatial distribution layers for highly sensitive parameters could be 
constructed by a specific land surface classification (e.g. wetland types, biome types, etc.), which is something that has not been considered in recent studies (Melton et al., 2013; Wania et al., 2013), but which is important for the evaluation of wetland $\mathrm{CH}_{4}$ emissions, especially at the regional or global scale. Better parameterization and evaluation of the model can potentially reduce the uncertainties in wetland $\mathrm{CH}_{4}$ emissions response to projected climate change (Melton et al., 2013).

Further modelling, observational and data collecting works should be carried out to reduce uncertainties and enable more accurate simulations. Firstly, studies have pointed out that $\mathrm{CH}_{4}$ emissions can be predicted well, but with incorrect contributions of production, oxidation and different transport (Riley et al., 2011; Melton et al., 2013). Further investigation should be conducted to examine methane fluxes from different transport pathways, the proportion of $\mathrm{CH}_{4}$ production and oxidation, as well as the spatial patterns of these processes across wide geographic locations. Also, support is needed from explicit site observations of $\mathrm{CH}_{4}$ emission processes, and relative physical and biogeochemical state variables (Melton et al., 2013). Secondly, the site-based simulations indicate that the model struggles to capture the peak emissions that are largely contributed by ebullition process. Though the process is hard to predict, preliminary improvement should be considered in the next stage. For example, a lower threshold could be used in the growing season, thus with higher ebullition (Spahni et al., 2011). Thirdly, in this current study, only one PFT was added for wetlands without considering specific wetland plants type (e.g. graminoids, sedges, sphagnum, moss). The model could be improved by considering the spatial characteristics of wetland vegetation, as well as including different effects of vascular and nonvascular plants on $\mathrm{CH}_{4}$ emissions processes, especially for the oxidation and plant-mediated transport processes. Fourthly, $\mathrm{CH}_{4}$ oxidation rate was simulated as a function of $\mathrm{CH}_{4}$ concentration, soil temperature and soil redox potential in this study. Redox potential was used to represent the condition of soil electron acceptor. Although methane oxidation can happen under anaerobic conditions with available alternative electron acceptors (Zhuang et al., 2004), modelling dynamic changes of oxygen in the profile, including diffusion through soil layers and transport from atmosphere via vascular plants, is essential in the methanotrophic process (Wania et al., 2010). These processes need to be considered explicitly in further model development. Finally, more data from literature reviews or field measurements are needed to conduct the parameterization of the water table module and test model simulation performance, because the water table is an important factor controlling $\mathrm{CH}_{4}$ production, consumption and transportation processes.

\section{Summary and conclusions}

This study has introduced the successful integration of a $\mathrm{CH}_{4}$ biogeochemistry module incorporating $\mathrm{CH}_{4}$ production, oxidation and transportation processes into an existing DGVM (IBIS). Factors controlling $\mathrm{CH}_{4}$ emission processes, such as soil temperature, redox potential and $\mathrm{pH}$, were specified into the model. A water table module was also integrated into DGVM to improve hydrological processes for wetland simulation. Sensitivity analysis indicates that the release ratio of $\mathrm{CH}_{4}$ to $\mathrm{CO}_{2}$ and $Q_{10}$ for $\mathrm{CH}_{4}$ production are two major controlling factors in $\mathrm{CH}_{4}$ emission modelling. These two parameters were subsequently calibrated to data obtained from 19 sites collected from approximately 35 studies across different wetlands globally, which is a more extensive sampling than previous models have encompassed. Having a heterogeneous spatial distribution, $r$ ranged from 0.1 to 0.7 with a mean value of 0.23 , and the $Q_{10}$ for $\mathrm{CH}_{4}$ production ranged from 1.6 to 4.5 with a mean value of 2.48 . We found that the TRIPLEX-GHG was able to capture patterns in temporal variation of $\mathrm{CH}_{4}$ emission, but was unable to simulate daily details or the emission pulse. Results suggest that the TRIPLEX-GHG model can be applied to different wetlands under varying conditions. It should contribute to the scientific modelling community by accounting for GHG exchange and the budgeting of terrestrial ecosystems, especially the $\mathrm{CH}_{4}$ budget at both regional and global scales.

Acknowledgements. This study was funded by the National Basic Research Programme of China (2013CB956602), the National Natural Science Foundation of China (41201079), the Programme of NCET, the Start-up Funds (Z111021203) and Basic Research Funds (Z109021204) of Northwest A\&F University, the Specialized Research Fund for the Doctoral Programme of Higher Education of China (20120204120007), and the Natural Sciences and Engineering Research Council of Canada Discovery Grant. The authors would like to thank three anonymous reviewers for their valuable comments and constructive suggestions which greatly improved the paper.

Edited by: A. Stenke

\section{References}

Arneth, A., Sitch, S., Bondeau, A., Butterbach-Bahl, K., Foster, P., Gedney, N., de Noblet-Ducoudré, N., Prentice, I. C., Sanderson, M., Thonicke, K., Wania, R., and Zaehle, S.: From biota to chemistry and climate: towards a comprehensive description of trace gas exchange between the biosphere and atmosphere, Biogeosciences, 7, 121-149, doi:10.5194/bg-7-121-2010, 2010.

Bartlett, D. S., Bartlett, K. B., Hartman, J. M., Harriss, R. C., Sebacher, D. I., Pelletier-Travis, R., Dow, D. D., and Brannon, D. P.: Methane emissions from the Florida Everglades: Patterns of variability in a regional wetland ecosystem, Global Biogeochem. Cy., 3, 363-374, doi:10.1029/GB003i004p00363, 1989. 
Bartlett, K. B., Crill, P. M., Sebacher, D. I., Harriss, R. C., Wilson, J. O., and Melack, J. M.: Methane Flux From the Central Amazonian Floodplain, J. Geophys. Res., 93, 1571-1582, doi:10.1029/JD093iD02p01571, 1988.

Bartlett, K. B., Crill, P. M., Bonassi, J. A., Richey, J. E., and Harriss, R. C.: Methane flux from the Amazon River floodplain: emissions during rising water, J. Geophys. Res., 95, 16773-16788, 1990.

Batjes, N. H.: ISRIC-WISE derived soil properties on a 5 by 5 arcminutes global grid, Report 2006/02, available at: http://www. isric.org (last access: 9 May 2014), ISRIC-World Soil Information, Wageningen (with data set), 2006.

Boon, P. I.: Methanogenesis in the sediments of an Australian freshwater wetland: Comparison with aerobic decay, and factors controlling methanogenesis, Fems Microbiol. Ecol., 18, 175-190, doi:10.1016/0168-6496(95)00053-5, 1995.

Burke Jr., R. A., Barber, T. R., and Sackett, W. M.: Methane flux and stable hydrogen and carbon isotope composition of sedimentary methane from the Florida Everglades, Global Biogeochem. Cy., 2, 329-340, doi:10.1029/GB002i004p00329, 1988.

Cao, M., Dent, J. B., and Heal, O. W.: Modeling methane emissions from rice paddies, Global Biogeochem. Cy., 9, 183-195, doi:10.1029/94gb03231, 1995.

Cao, M., Marshall, S., and Gregson, K.: Global carbon exchange and methane emissions from natural wetlands: Application of a process-based model, J. Geophys. Res.-Atmos., 101, 1439914414, 1996.

Chen, H., Yao, S., Wu, N., Wang, Y., Luo, P., Tian, J., Gao, Y., and Sun, G.: Determinants influencing seasonal variations of methane emissions from alpine wetlands in Zoige Plateau and their implications, J. Geophys. Res., 113, D12303, doi:10.1029/2006jd008072, 2008.

Chen, H., Zhu, Q., Peng, C., Wu, N., Wang, Y., Fang, X., Jiang, H., Xiang, W., Chang, J., Deng, X., and Yu, G.: Methane emissions from rice paddies natural wetlands, and lakes in China: synthesis and new estimate, Glob. Change Biol., 19, 19-32, doi:10.1111/gcb.12034, 2013.

Chen, Y. H. and Prinn, R. G.: Atmospheric modeling of high- and low-frequency methane observations: Importance of interannually varying transport, J. Geophys. Res.-Atmos., 110, D10303, doi:10.1029/2004jd005542, 2005.

Ciais, P., Sabine, C., Bala, G., Bopp, L., Brovkin, V., Canadell, J., Chhabra, A., DeFries, R., Galloway, J., Heimann, M., Jones, C., Quéré, C. L., Myneni, R. B., Piao, S., and Thornton, P.: Carbon and Other Biogeochemical Cycles, Cambridge University Press, Cambridge, United Kingdom and New York, NY, USA, 465-570, 2013.

Clement, R. J., Verma, S. B., and Verry, E. S.: Relating Chamber Measurements to Eddy-Correlation Measurements of Methane Flux, J. Geophys. Res.-Atmos., 100, 21047-21056, 1995.

Cramer, W., Bondeau, A., Woodward, F. I., Prentice, I. C., Betts, R. A., Brovkin, V., Cox, P. M., Fisher, V., Foley, J. A., Friend, A. D., Kucharik, C., Lomas, M. R., Ramankutty, N., Sitch, S., Smith, B., White, A., and Young-Molling, C.: Global response of terrestrial ecosystem structure and function to $\mathrm{CO}_{2}$ and climate change: results from six dynamic global vegetation models, Glob. Change. Biol., 7, 357-373, 2001.
Cui, B.: Estimation of $\mathrm{CH}_{4}$ emission from Sanjiang plain, scientia Geographica Sinica, 17, 93-95, 1997 (in Chinese with English abstract).

Devol, A. H., Richey, J. E., Clark, W. A., King, S. L., and Martinelli, L. A.: Methane emissions to the troposphere from the Amazon floodplain, J. Geophys. Res., 93, 1583-1592, 1988.

Ding, W., Cai, Z., and Wang, D.: Preliminary budget of methane emissions from natural wetlands in China, Atmos. Environ., 38, 751-759, doi:10.1016/j.atmosenv.2003.10.016, 2004.

Dise, N. B.: Winter Fluxes of Methane from Minnesota Peatlands, Biogeochemistry, 17, 71-83, 1992.

Dise, N. B.: Methane Emission from Minnesota Peatlands - Spatial and Seasonal Variability, Global Biogeochem. Cy., 7, 123-142, 1993.

Dunfield, P., Knowles, R., Dumont, R., and Moore, T. R.: Methane production and consumption in temperate and subarctic peat soils: Response to temperature and $\mathrm{pH}$, Soil Biol. Biochem., 25, 321-326, 1993.

Enting, I., Heimann, M., and Wigley, T.: Future emissions and concentrations of carbon dioxide: Key ocean/atmosphere/land analyses, CSIRO Division of Atmospheric Research Technical Paper No. 31, CSIRO, Australia, 1994.

EPA: Methane-and-Nitrous-Oxide-Emissions-From-NaturalSources, Washington, DC 20460, 2010.

Fiedler, S. and Sommer, M.: Methane emissions, groundwater levels and redox potentials of common wetland soils in a temperate-humid climate, Global Biogeochem. Cy., 14, 10811093, doi:10.1029/1999gb001255, 2000.

Foley, J. A., Colin, P. I., Ramankutty, N., Levis, S., Pollard, D., Sitch, S., and Haxeltine, A.: An integrated biosphere model of land surface processes, terrestrial carbon balance, and vegetation dynamics, Global Biogeochem. Cy., 10, 603-628, 1996.

Frolking, S. and Crill, P.: Climate Controls on Temporal Variability of Methane Flux from a Poor Fen in Southeastern NewHampshire - Measurement and Modeling, Global Biogeochem. Cy., 8, 385-397, doi:10.1029/94gb01839, 1994.

Gedney, N., Cox, P. M., and Huntingford, C.: Climate feedback from wetland methane emissions, Geophys. Res. Lett., 31, L20503, doi:10.1029/2004g1020919, 2004.

Granberg, G., Grip, H., Ottosson Löfvenius, M., Sundh, I., Svensson, B. H., and Nilsson, M.: A simple model for simulation of water content, soil frost, and soil temperatures in boreal mixed mires, Water. Resour. Res., 35, 3771-3782, doi:10.1029/1999wr900216, 1999.

Granberg, G., Ottosson-Lofvenius, M., Grip, H., Sundh, I., and Nilsson, M.: Effect of climatic variability from 1980 to 1997 on simulated methane emission from a boreal mixed mire in northern Sweden, Global Biogeochem. Cy., 15, 977-991, 2001.

Hao, Q., Wang, Y., Song, C., Liu, G., Wang, Y., and Wang, M.: Study of $\mathrm{CH}_{4}$ Emission From Wetlands in Sanjiang Plain, J. Soil Water Conserv., 18, 194-199, 2004 (in Chinese with English abstract).

Harriss, R. C., Sebacher, D. I., Bartlett, K. B., Bartlett, D. S., and Crill, P. M.: Sources of atmospheric methane in the south Florida environment, Global Biogeochem. Cy., 2, 231-243, doi:10.1029/GB002i003p00231, 1988.

Hartmann, D. L., Tank, A. M. G. K., Rusticucci, M., Alexander, L. V., Brönnimann, S., Charabi, Y., Dentener, F. J., Dlugokencky, E. J., Easterling, D. R., Kaplan, A., Soden, B. J., Thorne, P. W., 
Wild, M., and Zhai, P. M.: Observations: Atmosphere and Surface, Cambridge University Press, Cambridge, United Kingdom and New York, NY, USA, 165-179, 2013.

Huang, Y., Sun, W. J., Zhang, W., Yu, Y. Q., Su, Y. H., and Song, C. C.: Marshland conversion to cropland in northeast China from 1950 to 2000 reduced the greenhouse effect, Glob. Change Biol., 16, 680-695, doi:10.1111/j.1365-2486.2009.01976.x, 2010.

Ito, A. and Inatomi, M.: Use of a process-based model for assessing the methane budgets of global terrestrial ecosystems and evaluation of uncertainty, Biogeosciences, 9, 759-773, doi:10.5194/bg9-759-2012, 2012.

Jackowicz-Korczyński, M., Christensen, T. R., Bäckstrand, K., Crill, P., Friborg, T., Mastepanov, M., and Ström, L.: Annual cycle of methane emission from a subarctic peatland, J. Geophys. Res., 115, G02009, doi:10.1029/2008jg000913, 2010.

Keeling, C. D., Piper, S. C., Bacastow, R. B., Wahlen, M., Whorf, T. P., Heimann, M., and Meijer, H. A.: Atmospheric $\mathrm{CO}_{2}$ and ${ }^{13} \mathrm{CO}_{2}$ exchange with the terrestrial biosphere and oceans from 1978 to 2000: observations and carbon cycle implications, in: A History of Atmospheric $\mathrm{CO}_{2}$ and its effects on Plants Animals and Ecosystems, edited by: Ehleringer, J. R., Cerling, T. E., and Dearing, M. D., Springer Verlag, New York, 83-113, 2005.

Kirschke, S., Bousquet, P., Ciais, P., Saunois, M., Canadell, J. G., Dlugokencky, E. J., Bergamaschi, P., Bergmann, D., Blake, D. R., Bruhwiler, L., Cameron-Smith, P., Castaldi, S., Chevallier, F., Feng, L., Fraser, A., Heimann, M., Hodson, E. L., Houweling, S., Josse, B., Fraser, P. J., Krummel, P. B., Lamarque, J.F., Langenfelds, R. L., Le Quere, C., Naik, V., O’Doherty, S., Palmer, P. I., Pison, I., Plummer, D., Poulter, B., Prinn, R. G., Rigby, M., Ringeval, B., Santini, M., Schmidt, M., Shindell, D. T., Simpson, I. J., Spahni, R., Steele, L. P., Strode, S. A., Sudo, K., Szopa, S., van der Werf, G. R., Voulgarakis, A., van Weele, M., Weiss, R. F., Williams, J. E., and Zeng, G.: Three decades of global methane sources and sinks, Nat. Geosci., 6, 813-823, doi:10.1038/ngeo1955, 2013.

Kucharik, C. J., Foley, J. A., Delire, C., Fisher, V. A., Coe, M. T., lenters, J. D., Young-Molling, C., and Ramankutty, N.: Testing the performance of a Dynamic Global Ecosystem Model: Water balance, carbon balance, and vegetation structure, Global Biogeochem. Cy., 14, 795-825, 2000.

Kucharik, C. J., Barford, C. C., El Maayar, M., Wofsy, S. C., Monson, R. K., and Baldocchi, D. D.: A multiyear evaluation of a Dynamic Global Vegetation Model at three AmeriFlux forest sites: Vegetation structure, phenology, soil temperature, and $\mathrm{CO}_{2}$ and $\mathrm{H}_{2} \mathrm{O}$ vapor exchange, Ecol. Model., 196, 1-31, doi:10.1016/j.ecolmodel.2005.11.031, 2006.

Lenhart, T., Eckhardt, K., Fohrer, N., and Frede, H.-G.: Comparison of two different approaches of sensitivity analysis, Phys. Chem. Earth, 27, 645-654, 2002.

Li, C. S.: Modeling Trace Gas Emissions from Agricultural Ecosystems, Nutr. Cycl. Agroecosys., 58, 259-276, doi:10.1023/a:1009859006242, 2000.

Liu, J., Price, D., and Chen, J.: Nitrogen controls on ecosystem carbon sequestration: a model implementation and application to Saskatchewan, Canada, Ecol. Model., 186, 178-195, doi:10.1016/j.ecolmodel.2005.01.036, 2005.

Ma, K., You, L., Liu, J., and Zhang, M.: A Hybrid Wetland Map for China: A Synergistic Approach Using Cen- sus and Spatially Explicit Datasets, Plos One, 7, e47814, doi:10.1371/journal.pone.0047814, 2012.

Melack, J. M., Hess, L. L., Gastil, M., Forsberg, B. R., Hamilton, S. K., Lima, I. B. T., and Novo, E. M. L. M.: Regionalization of methane emissions in the Amazon Basin with microwave remote sensing, Glob. Change. Biol., 10, 530-544, doi:10.1111/j.13652486.2004.00763.x, 2004.

Melloh, R. A. and Crill, P. M.: Winter methane dynamics in a temperate peatland, Global Biogeochem. Cy., 10, 247-254, 1996.

Melton, J. R., Wania, R., Hodson, E. L., Poulter, B., Ringeval, B., Spahni, R., Bohn, T., Avis, C. A., Beerling, D. J., Chen, G., Eliseev, A. V., Denisov, S. N., Hopcroft, P. O., Lettenmaier, D. P., Riley, W. J., Singarayer, J. S., Subin, Z. M., Tian, H., Zürcher, S., Brovkin, V., van Bodegom, P. M., Kleinen, T., Yu, Z. C., and Kaplan, J. O.: Present state of global wetland extent and wetland methane modelling: conclusions from a model intercomparison project (WETCHIMP), Biogeosciences, 10, 753788, doi:10.5194/bg-10-753-2013, 2013.

Meng, L., Hess, P. G. M., Mahowald, N. M., Yavitt, J. B., Riley, W. J., Subin, Z. M., Lawrence, D. M., Swenson, S. C., Jauhiainen, J., and Fuka, D. R.: Sensitivity of wetland methane emissions to model assumptions: application and model testing against site observations, Biogeosciences, 9, 2793-2819, doi:10.5194/bg-92793-2012, 2012.

Moore, T. R. and Knowles, R.: Methane Emissions from Fen, Bog and Swamp Peatlands in Quebec, Biogeochemistry, 11, 45-61, 1990.

Moore, T. R., De Young, A., Bubier, J. L., Humphreys, E. R., Lafleur, P. M., and Roulet, N. T.: A Multi-Year Record of Methane Flux at the Mer Bleue Bog, Southern Canada, Ecosystems, 14, 646-657, doi:10.1007/s10021-011-9435-9, 2011.

Myhre, G., Shindell, D., Bréon, F.-M., Collins, W., Fuglestvedt, J., Huang, J., Koch, D., J.-F. Lamarque, D., Lee, B. M., Nakajima, T., Robock, A., Stephens, G., Takemura, T., and Zhang, H.: Anthropogenic and Natural Radiative Forcing, Cambridge University Press, Cambridge, United Kingdom and New York, NY, USA, 731-738, 2013.

Nisbet, E. G., Dlugokencky, E. J., and Bousquet, P.: Methane on the rise - again, Science, 343, 493-495, doi:10.1126/science.1247828, 2014.

Ojima, D. S., Holland, E. A., Melillo, J. M., Mosier, A. R., and Robertson, G. P.: TRAGNET Workshop Report: Building a U.S. Trace Gas Network, Pingree Park, Colorado, USA, 1992.

Panikov, N. S. and Dedysh, S. N.: Cold season $\mathrm{CH}_{4}$ and $\mathrm{CO}_{2}$ emission from boreal peat bogs (West Siberia): Winter fluxes and thaw activation dynamics, Global Biogeochem. Cy., 14, 10711080, 2000.

Pelletier, L., Moore, T. R., Roulet, N. T., Garneau, M., and Beaulieu-Audy, V.: Methane fluxes from three peatlands in the La Grande Riviere watershed, James Bay lowland, Canada, J. Geophys. Res.-Biogeo., 112, G01018, doi:10.1029/2006jg000216, 2007.

Peng, C., Liu, J., Dang, Q., Apps, M. J., and Jiang, H.: TRIPLEX: A generic hybrid model for predicting forest growth and carbon and nitrogen dynamics, Ecol. Model., 153, 109-130, doi:10.1016/s0304-3800(01)00505-1, 2002.

Peng, C. H., Liu, J. X., Zhu, Q. A., and Chen, H.: Framework for Integrating greenhouse gas emission processes into a dynamic 
global vegetation model: TRIPLEX-GHG model development and testing, North America Carbon Program, New Mexico, 2013.

Petrescu, A. M. R., van Beek, L. P. H., van Huissteden, J., Prigent, C., Sachs, T., Corradi, C. A. R., Parmentier, F. J. W., and Dolman, A. J.: Modeling regional to global $\mathrm{CH}_{4}$ emissions of boreal and arctic wetlands, Global Biogeochem. Cy., 24, GB4009, doi:10.1029/2009gb003610, 2010.

Prentice, I. C., Webb, R. S., Ter-Mikhaelian, M. T., Solomon, A. M., Smith, T. M., Pitovranov, S. E., Nikolov, N. T., Minin, A. A., Leemans, R., Lavorel, S., Korzukhin, M. D., Hrabovszky, J. P., Helmisaari, H. O., Harrison, S. P., Emanuel, W. R., and Bonan, G. B.: Developing a global vegetation dynamics model : results of an IIASA summer workshop, Laxenburg, Austria, 52 pp., 1989.

Riley, W. J., Subin, Z. M., Lawrence, D. M., Swenson, S. C., Torn, M. S., Meng, L., Mahowald, N. M., and Hess, P.: Barriers to predicting changes in global terrestrial methane fluxes: analyses using CLM4Me, a methane biogeochemistry model integrated in CESM, Biogeosciences, 8, 1925-1953, doi:10.5194/bg-8-19252011, 2011.

Rinne, J., Riutta, T., Pihlatie, M., Aurela, M., Haapanala, S., Tuovinen, J. P., Tuittila, E. S., and Vesala, T.: Annual cycle of methane emission from a boreal fen measured by the eddy covariance technique, Tellus B, 59, 449-457, doi:10.1111/j.16000889.2007.00261.x, 2007.

Saarnio, S., Alm, J., Silvola, J., Lohila, A., Nykänen, H., and Martikainen, P. J.: Seasonal variation in $\mathrm{CH}_{4}$ emissions and production and oxidation potentials at microsites on an oligotrophic pine fen, Oecologia, 110, 414-422, doi:10.1007/s004420050176, 1997.

Sass, R. L., Fisher, F. M., Harcombe, P. A., and Turner, F. T.: Methane production and emission in a Texas rice field, Global Biogeochem. Cy., 4, 47-68, doi:10.1029/GB004i001p00047, 1990.

Segers, R.: Methane Production and Methane Consumption: A Review of Processes Underlying Wetland Methane Fluxes, Biogeochemistry, 41, 23-51, 1998.

Sellers, P. J., Hall, F. G., Kelly, R. D., Black, A., Baldocchi, D., Berry, J., Ryan, M., Ranson, K. J., Crill, P. M., Lettenmaier, D. P., Margolis, H., Cihlar, J., Newcomer, J., Fitzjarrald, D., Jarvis, P. G., Gower, S. T., Halliwell, D., Williams, D., Goodison, B., Wickland, D. E., and Guertin, F. E.: BOREAS in 1997: Experiment overview, scientific results, and future directions, J. Geophys. Res.-Atmos., 102, 28731-28769, 1997.

Shannon, R. D. and White, J. R.: A Three-Year Study of Controls on Methane Emissions from Two Michigan Peatlands, Biogeochemistry, 27, 35-60, 1994.

Shannon, R. D., White, J. R., Lawson, J. E., and Gilmour, B. S.: Methane efflux from emergent vegetation in peatlands, J. Ecol., 84, 239-246, 1996.

Shindell, D. T., Walter, B. P., and Faluvegi, G.: Impacts of climate change on methane emissions from wetlands, Geophys. Res. Lett., 31, L21202, doi:10.1029/2004g1021009, 2004.

Shoemaker, J. K. and Schrag, D. P.: Subsurface characterization of methane production and oxidation from a New Hampshire wetland, Geobiology, 8, 234-243, doi:10.1111/j.14724669.2010.00239.x, 2010.

Song, C., Xu, X., Tian, H., and Wang, Y.: Ecosystem-atmosphere exchange of $\mathrm{CH}_{4}$ and $\mathrm{N}_{2} \mathrm{O}$ and ecosystem respiration in wetlands in the Sanjiang Plain, Northeastern China, Glob. Change Biol., 15, 692-705, doi:10.1111/j.1365-2486.2008.01821.x, 2009.

Spahni, R., Wania, R., Neef, L., van Weele, M., Pison, I., Bousquet, P., Frankenberg, C., Foster, P. N., Joos, F., Prentice, I. C., and van Velthoven, P.: Constraining global methane emissions and uptake by ecosystems, Biogeosciences, 8, 1643-1665, doi:10.5194/bg8-1643-2011, 2011.

Stocker, B. D., Roth, R., Joos, F., Spahni, R., Steinacher, M., Zaehle, S., Bouwman, L., Xu, R., and Prentice, I. C.: Multiple greenhouse-gas feedbacks from the land biosphere under future climate change scenarios, Nature Climate Change, 3, 666-672, doi:10.1038/nclimate1864, 2013.

Strom, L., Mastepanov, M., and Christensen, T. R.: Species-specific effects of vascular plants on carbon turnover and methane emissions from wetlands, Biogeochemistry, 75, 65-82, 2005.

Svensson, B. H., Christensen, T. R., Johansson, E., and Oquist, M.: Interdecadal changes in $\mathrm{CO}_{2}$ and $\mathrm{CH}_{4}$ fluxes of a subarctic mire: Stordalen revisited after 20 years, Oikos, 85, 22-30, 1999.

Tian, H., Xu, X., Liu, M., Ren, W., Zhang, C., Chen, G., and Lu, C.: Spatial and temporal patterns of $\mathrm{CH}_{4}$ and $\mathrm{N}_{2} \mathrm{O}$ fluxes in terrestrial ecosystems of North America during 1979-2008: application of a global biogeochemistry model, Biogeosciences, 7 , 2673-2694, doi:10.5194/bg-7-2673-2010, 2010.

Valentine, D. W., Holland, E. A., and Schinel, D. S.: Ecosystem and physical controls over methane production in northern wetlands, J. Geophys. Res., 99, 1563-1571, 1994.

van Huissteden, J., van den Bos, R., and Alvarez, I. M.: Modelling the effect of water-table management on $\mathrm{CO}_{2}$ and $\mathrm{CH}_{4}$ fluxes from peat soils, Netherlands Journal of Geosciences, 85, 3-18, 2006.

Walter, B. P. and Heimann, M.: A process-based, climate-sensitive model to derive methane emissions from natural wetlands: Application to five wetland sites, sensitivity to model parameters, and climate, Global Biogeochem. Cy., 14, 745-765, doi:10.1029/1999gb001204, 2000.

Walter, B. P., Heimann, M., and Matthews, E.: Modeling modern methane emissions from natural wetlands 2 . Interannual variations 1982-1993, J. Geophys. Res., 106, 34207-34219, doi:10.1029/2001jd900164, 2001a.

Walter, B. P., Heimann, M., and Matthews, E.: Modeling modern methane emissions from natural wetlands 1 . Model description and results, J. Geophys. Res., 106, 34189-34206, doi:10.1029/2001jd900165, 2001b.

Wang, D., Lu, X., Ding, W., Cai, Z., Gao, J., and Yang, F.: Methane emission from marshes in Zoige Plateau, Adv. Earth Sci., 17, 877-880, 2002a.

Wang, D., Lu, X., Ding, W., Cai, Z., and Wang, Y.: Comparison of Methane Emission from Marsh and Paddy Field in Sanjiang Plain, Scientia Geographica Sinica, 22, 500-503, 2002b (in Chinese with English abstract).

Wang, Y. P., Law, R. M., and Pak, B.: A global model of carbon, nitrogen and phosphorus cycles for the terrestrial biosphere, Biogeosciences, 7, 2261-2282, doi:10.5194/bg-7-2261-2010, 2010.

Wang, Z. P., Delaune, R. D., Masscheleyn, P. H., and Patrick, W. H.: Soil Redox and Ph Effects on Methane Production in a Flooded Rice Soil, Soil Sci. Soc. Am. J., 57, 382-385, 1993.

Wania, R., Ross, I., and Prentice, I. C.: Integrating peatlands and permafrost into a dynamic global vegetation model: 2. Evaluation and sensitivity of vegetation and car- 
bon cycle processes, Global. Biogeochem. Cy., 23, GB3015, doi:10.1029/2008gb003413, 2009a.

Wania, R., Ross, I., and Prentice, I. C.: Integrating peatlands and permafrost into a dynamic global vegetation model: 1. Evaluation and sensitivity of physical land surface processes, Global. Biogeochem. Cy., 23, GB3014, doi:10.1029/2008gb003412, 2009b.

Wania, R., Ross, I., and Prentice, I. C.: Implementation and evaluation of a new methane model within a dynamic global vegetation model: LPJ-WHyMe v1.3.1, Geosci. Model Dev., 3, 565-584, doi:10.5194/gmd-3-565-2010, 2010.

Wania, R., Melton, J. R., Hodson, E. L., Poulter, B., Ringeval, B., Spahni, R., Bohn, T., Avis, C. A., Chen, G., Eliseev, A. V., Hopcroft, P. O., Riley, W. J., Subin, Z. M., Tian, H., van Bodegom, P. M., Kleinen, T., Yu, Z. C., Singarayer, J. S., Zürcher, S., Lettenmaier, D. P., Beerling, D. J., Denisov, S. N., Prigent, C., Papa, F., and Kaplan, J. O.: Present state of global wetland extent and wetland methane modelling: methodology of a model inter-comparison project (WETCHIMP), Geosci. Model Dev., 6, 617-641, doi:10.5194/gmd-6-617-2013, 2013.

Weiss, R., Shurpali, N. J., Sallantaus, T., Laiho, R., Laine, J., and Alm, J.: Simulation of water table level and peat temperatures in boreal peatlands, Ecol. Model., 192, 441-456, doi:10.1016/j.ecolmodel.2005.07.016, 2006.

Westermann, P.: Temperature regulation of methanogenesis in wetlands, Chemosphere, 26, 321-328, 1993.

Whalen, S. C. and Reeburgh, W. S.: Interannual variations in tundra methane emission: A 4-year time series at fixed sites, Global Biogeochem. Cy., 6, 139-159, doi:10.1029/92gb00430, 1992.
Whiting, G. J. and Chanton, J. P.: Primary Production Control of Methane Emission from Wetlands, Nature, 364, 794-795, 1993.

Wickland, K. P., Striegl, R. G., Mast, M. A., and Clow, D. W.: Interannual variation of soil respiration in two New England forests, Global Biogeochem Cy., 15, 321-335, doi:10.1029/2000gb001325, 2001.

Willmott, C. J.: On the Validation of Models, Phys. Geogr., 2, 184 194, 1981.

Yang, J., Liu, J., Wang, J., Yu, J., Sun, Z., and Li, X.: Emissions of $\mathrm{CH}_{4}$ and $\mathrm{N}_{2} \mathrm{O}$ from a wetland in the Sanjiang plain, J. Plant Ecol., 30, 432-440, 2006 (in Chinese with English abstract).

Zhang, Y., Li, C. S., Trettin, C. C., Li, H., and Sun, G.: An integrated model of soil, hydrology, and vegetation for carbon dynamics in wetland ecosystems, Global Biogeochem. Cy., 16, 1061, doi:10.1029/2001gb001838, 2002.

Zhuang, Q. and Crill, P.: NCEAS 10645: Toward an adequate quantification of $\mathrm{CH}_{4}$ emissions from land ecosystems: Integrating field and in-situ observations, satellite data, and modeling. Sallies Fen $\mathrm{NH} \mathrm{CH}_{4}$ Flux 1994-2001, National Center for Ecological Analysis and Synthesis and Stockholm University, 2008.

Zhuang, Q., Melillo, J. M., Kicklighter, D. W., Prinn, R. G., McGuire, A. D., Steudler, P. A., Felzer, B. S., and Hu, S.: Methane fluxes between terrestrial ecosystems and the atmosphere at northern high latitudes during the past century: A retrospective analysis with a process-based biogeochemistry model, Global Biogeochem. Cy., 18, GB3010, doi:10.1029/2004gb002239, 2004. 